\title{
ARTYKutY
}

Klio. Czasopismo poświęcone dziejom Polski i powszechnym PL ISSN 1643-8191, t. 38 (3)/2016, s. 75-120

(c) (i) $\ominus$

http://dx.doi.org/10.12775/KLIO.2016.033

MARIUSZ MENZ*

\section{Obrazy Galicji w szkolnych podręcznikach historii do szkół średnich od końca XIX wieku do upadku PRL-u: przyczynek do polityki historycznej}

\author{
Means of presentation of Galicia in textbooks on History \\ for secondary schools from the end of the nineteenth century \\ to the fall of communist Poland: analysis of historical policy
}

Streszczenie: Artykuł przedstawia, w jaki sposób autorzy szkolnych podręczników historii prezentowali w nich Galicję. Autor wykazuje, że sposoby prezentowania dawnej prowincji habsburskiej wynikały $\mathrm{z}$ dominującej w danym okresie polityki historycznej. Przed 1918 roku podręczniki powstałe w Galicji odzwierciedlały zatem poglądy konserwatywnych stańczyków i akcentowały lojalizm wobec Habsburgów. W okresie II Rzeczypospolitej (po 1926 roku) Galicję przedstawiano jako polski Piemont, co było wynikiem polityki historycznej sanacji. Po II wojnie światowej Galicja była z kolei przedstawiana według założeń ideologii marksistowskiej i odzwierciedlała polityką historyczną państwa komunistycznego.

* Instytut Historii, Uniwersytet im. A. Mickiewicza, ul. Umultowska 89d, 61-809 Poznań; e-mail: mmenz@poczta.onet.pl. 
Abstract: The article shows how authors of school textbooks on history presented Galicia. The author indicates that the ways of presenting the former Habsburg province resulted from historical policy dominant in a given period of time. Therefore, textbooks created in Galicia before 1918 reflected the point of view of conservative formation „stańczycy” and accentuated loyalty to the Habsburgs. During the Second Republic of Poland (after 1926 years) Galicia was presented as a Polish „Piemont”, which was the result of historical policy introduced by a political formation called „sanacja”. After the Second World War, Galicia was presented according to Marxist ideology in turn and assumptions reflecting the historical policy of the communist state.

Słowa kluczowe: Galicja, podręczniki historii, szkoły średnie, polityka historyczna

Keywords: Galicia, history textbooks, secondary schools, historical policy

W

ostatnich latach możemy zaobserwować wzrost zainteresowań historią Galicji, czego przejawem są nie tylko liczne publikacje i konferencje, ale także międzynarodowe projekty oraz wystawy, które przybliżają fenomen tej dawnej habsburskiej prowincji ${ }^{1}$. Całkiem niedawno Międzynarodowe Centrum Kultury w Krakowie we współpracy z Wien Museum przygotowało wystawę pt. „Mit Galicji”, której ekspozycja wzbudziła ogromne zainteresowanie nie tylko w Krakowie i w Wiedniu, gdzie można ją było oglądać, ale także na Ukrainie, której zachodnia część po rzekę Zbrucz stanowiła przecież wschodnią część Galicji (ukr. Hatyczyna) ${ }^{2}$.

${ }^{1}$ Literatura dotycząca oświaty galicyjskiej jest bardzo obfita. Jej szczegółowe zestawienie zob. Bibliografia dziejów oświaty i wychowania w Galicji 1772-1918; cz. 1: Opracowania do 1990, red. A. Meissner, Lublin 2015; cz. 2: Źródta drukowane, red. A. Meissner, J. Dybiec, Rzeszów 2007; cz. 3: Opracowania z lat 1991-2008, red. A. Meissner, K. Szmyd, Rzeszów 2015. Z najnowszych publikacji zob. Szkolnictwo i oświata $w$ Galicji 1772-1918, red. J. Dybiec, J. Krawczyk, A. Meissner, K. Szmyd, Rzeszów 2015; J. Falkowska, Myśl wychowania narodowego w Galicji okresu autonomii. Twórcy i idee, Toruń 2013; J. Moklak, Hatyczyna contra Galicja: ukraińskie szkolnictwo średnie i wyższe w debatach Sejmu Krajowego galicyjskiego 1907-1914, Kraków 2013.

2 Wystawa odbyła się w Krakowie w dniach 9 X 2014-8 III 2015, a w Wiedniu 25 III 2015-30 VIII 2015. We Lwowie na temat tej wystawy pisano m.in. w Kurierze Galicyjskim [online], dostępny na: http://kuriergalicyjski.com/kultura/wystawy/3981-mit-galicji [dostęp: 12 XII 2014] oraz http://kuriergalicyjski.com/spolechenstwo/felietony-kg/4216-jak-szkodzi-mit-galicji [dostęp: 9 VI 2015]. 
Wystawie towarzyszył znakomicie zredagowany album, w którym - oprócz katalogu i licznych zdjęć - znalazło się ponad 20 tekstów autorów z Polski, Austrii, Ukrainy i USA ${ }^{3}$.

Co jednak ciekawe, żaden $\mathrm{z}$ artykułów nie odwoływał się do obrazu Galicji kreowanego przez szkołę (polską, austriacką czy ukraińska) ani nie podejmował problematyki Galicji z perspektywy szkolnych podręczników historii. A szkoda, gdyż podręczniki, tak samo jak wystawy, mogą być interpretowane w kategoriach polityki historycznej, którą rozumiem jako sferę oddziaływań perswazyjnych państwa i jej zinstytucjonalizowanych podmiotów na społeczeństwo (i jego poszczególne grupy) w celu kształtowania określonej (politycznie pożądanej) wizji przeszłości. Cechą polityki historycznej są zabiegi rekompozycji zastanego układu pamięci oraz tradycji, które zachodzą w momencie zmiany historycznej lub politycznej ${ }^{4}$. $\mathrm{Na}$ politykę historyczną wpływa także dyskurs tzw. elit symbolicznych, rozumianych w znaczeniu nadanym im przez Teuna van Dijka ${ }^{5}$. Do tych elit zaliczymy także autorów podręczników oraz nauczycieli.

Niniejszy artykuł jest zatem próbą częściowej rekompensaty tego braku, choć trzeba zastrzec, że jest ona zawężona tylko do podręczników polskich, obejmujących szczebel szkolnictwa średniego ogólnokształcącego. Poza analizą pozostały podręczniki do szkół niższego oraz zawodowego stopnia. Tekst nie wyczerpuje zatem tematu. Jest raczej jego zagajeniem. Wydaje się w związku z tym celowe, aby na Galicję spojrzeć także przez pryzmat podręczników austriackich, ukraińskich czy żydowskich - wówczas moglibyśmy uzyskać obraz dawnego kraju koronnego monarchii habsburskiej, widzianej z perspektywy zmieniającej się polityki historycznej poszczególnych państw: Polski, Austrii, Ukrainy czy Izraela. Uwzględnienie

${ }^{3}$ Mit Galicji, red. nauk. J. Purchla, W. Kos oraz Ż. Komar, M. Rydiger i W.M. Schwarz, Kraków 2014.

${ }^{4}$ Zob. A. Mencwel, Rodzinna Europa po raz pierwszy, Kraków 2009, s. 37-39. Zob. także hasło „polityka historyczna” autorstwa Joanny Kalickiej i Piotra Witka, [w:] Modi memorandi. Leksykon kultury pamięci, red. M. Saryusz-Wolska, R. Traba, [współpraca:] J. Kalicka, Warszawa 2014, s. 378-387.

${ }^{5}$ Zob. Dyskurs elit symbolicznych. Próba diagnozy, red. M. Czyżewski, K. Franczak, M. Nowicka, J. Stachowiak, Warszawa 2014. 
tego ostatniego wiąże się z istnieniem na terenie Galicji ogromnej diaspory żydowskiej, bez której opisu i analizy każdy obraz pozostanie niepełny.

Pierwszym krokiem do realizacji tego zadania może być inicjatywa dyrektora Stacji Naukowej Polskiej Akademii Nauk w Wiedniu Bogusława Dybasia, który zaproponował międzynarodowy projekt badawczy, mający na celu dokonanie komparatystycznej analizy podręczników historii funkcjonujących we wszystkich krajach koronnych dawnej c. k. monarchii. Uzyskane w ten sposób wyniki mogłyby dać odpowiedź, w jaki sposób kreowano obrazy zarówno całej monarchii, jak i jej poszczególnych części. Mogłyby też pokazać, w jaki sposób historia szkolna realizowała z jednej strony zadania państwowe (oficjalną politykę historyczna), a z drugiej zadania narodowe (nacjonalizując historię). Punktem wyjścia tej inicjatywy było dwudniowe sympozjum zorganizowane niedawno w Wiedniu, a poświęcone podręcznikom galicyjskim ${ }^{6}$.

\section{Ziemie polskie pod zaborami - jedna czy trzy historie?}

Galicja jest jedyną nazwą utworzoną przez państwo zaborcze, która przetrwała okres pozaborowy. Współczesny polski absolwent szkoły średniej ogólnokształcącej Galicję z pewnością skojarzy z „dobrym” cesarzem Franciszkiem Józefem i z autonomią, która dała Polakom szereg swobód, tak bardzo kontrastujących z sytuacją rodaków w dwóch pozostałych dzielnicach. $Z$ okresu przedautonomicznego zapamięta nasz absolwent zapewne nieudane powstanie krakowskie i rabację galicyjską, być może jeszcze Wiosnę Ludów. Czy coś więcej? Trudno powiedzieć, gdyż nikt do tej pory nie przeprowadził na ten temat reprezentatywnych badań.

Kiedy w 2013 roku zorganizowano w Poznaniu międzynarodową konferencję naukową poświęconą dziedzictwu zaborów, zatytułowano ją „Wielkopolska, Galicja i Królestwo Polskie. Jedna czy trzy historie?”7.

${ }^{6}$ Sympozjum odbyło się w Stacji Naukowej PAN w Wiedniu w dniach 27-28 VI 2016 i nosiło tytuł „Szkolne podręczniki do nauki historii w Galicji”.

7 Konferencja, której organizatorem był Instytut Historii UAM w Poznaniu, odbyła się w dniach 9-11 X 2013 r. 
Konferencja, mimo że jej pokłosiem stały się dwie monografie ${ }^{8}$, nie dała zasadniczej odpowiedzi na tytułowe pytanie. Pozwoliła natomiast wyraźnie zaakcentować linię demarkacyjną oddzielającą dwie odziedziczone po XIX wieku tradycje: tradycję romantyzmu politycznego (walk narodowo-wyzwoleńczych) oraz tradycję realizmu politycznego (pracy organicznej). Obie wpływały (i wpływaja) na realizowaną w danym momencie politykę historyczną oraz kreowały (i kreuja) zapotrzebowanie na określoną wizję narodu oraz egzemplifikujących ją bohaterów. Dość wspomnieć np. ostatnie postulaty budowania takiej polityki historycznej, która zrywałaby z „pedagogiką wstydu"'.

Pierwsza z tradycji odwołuje się do chwalebnej wizji narodu, który z bronią w ręku permanentnie walczył o niepodległość, składając na „ołtarzu ojczyzny" najwyższe ofiary. Ta tradycja pozwala z jednej strony kreować poczucie dumy z własnej przeszłości; $\mathrm{z}$ drugiej zawęża jednak pojęcie patriotyzmu do cycerońskiego Dulce et decorum est pro patria mori ${ }^{10}$.

Tradycja realizmu politycznego odwołuje się natomiast do wizji narodu racjonalnego, odrzucającego mickiewiczowskie „mierzenie sił na zamiary” i przedkładającego legalne (nieheroiczne?) formy działalności narodowej. Ta tradycja wystąpiła w dwóch wariantach: legalistycznym (Wielkopolska) i lojalistycznym (Galicja). W wariancie wielkopolskim praca organiczna nie wiązała się z lojalizmem - jej warunkiem i cechą wyróżniającą był tylko legalizm. Natomiast w Galicji było przeciwnie: tam dokonano afirmacji lojalizmu, czego symbolem stali się krakowscy stańczycy. Galicyjskie elity - w przeciwieństwie do wielkopolskich - zaangażowały się bowiem także

${ }^{8}$ Zob. Między polityka, historia a pamięcia historyczna. Studia z dziejów Polski okresu porozbiorowego, red. W. Łazuga, S. Paczos, Poznań 2015; Życie codzienne, gospodarka, kultura i spoteczeństwo polskie w latach 1772-1918. Rozprawy z dziejów ziem polskich w okresie zaborów, red. W. Łazuga, D. Szymczak, Poznań 2015.

${ }^{9}$ O przełamywaniu tzw. pedagogiki wstydu jako celu nowej polityki historycznej mówił w Krakowie 3 XII 2015 wiceminister spraw zagranicznych Jan Dziedziczak. Wiceminister użył tego określenia podczas otwarcia dwudniowej międzynarodowej konferencji naukowej pt. „Historia Polski w międzynarodowej perspektywie”, zorganizowanej przez Międzynarodowe Centrum Kultury w Krakowie oraz Ministerstwo Spraw Zagranicznych. Konferencję poprzedził wykład Adama Zamojskiego o prowokacyjnym tytule „Polska - kraj na Księżycu”.

${ }^{10}$ „Słodko i zaszczytnie jest umrzeć za ojczyznę”. Horacy, Pieśni. 
$\mathrm{w}$ życie polityczne Austrii i odegrały w niej niebagatelną rolę ${ }^{11}$. Czy jest to jednak powód do dumy? Czy fakt, że trzech Polaków piastowało naczelne funkcje w rządach austriackich ${ }^{12}$ podnosi nasze narodowe ego? Czy polityka historyczna eksponuje te kariery? Raczej nie. O Traugucie słyszeli wszyscy. O Gołuchowskim czy Badenim - raczej nieliczni.

Gdyby spojrzeć na cały wiek XIX z perspektywy przywołanych tradycji, to okazałoby się, że tradycja irredentystyczna wcale nie była w XIX wieku aż tak dominująca, jak nam się wydaje. Na pewno nie zdominowała historii zaboru pruskiego i austriackiego. To polityka historyczna, mająca przełożenie na programy i podręczniki szkolne, tak ją przedstawiła i ukształtowała w naszej pamięci kulturowej, wpływając tym samym na naszą świadomość narodową. Łatwiej jest bowiem kreować bohaterów walk niepodległościowych niż szermierzy pracy organicznej. Ci pierwsi, poza miejscem w podręcznikach, mają przecież także swoje "miejsca pamięci” (pomniki, tablice, nazwy ulic, patronaty szkół itp.). Dla drugich natomiast szansa „przebicia się" do kategorii narodowych bohaterów jest raczej znikoma. Mogą co najwyżej liczyć na lokalny kult, jak to się dzieje w przypadku wielkopolskich organiczników. Celnie ujął to Waldemar Łazuga:

W odczuciu młodego Polaka - przed pierwszą wojną światową, po drugiej i obecnie - to w Królestwie zawsze działo się najwięcej, w Galicji o wiele mniej, a w Wielkopolsce najmniej [...]. Królestwo ze swymi powstaniami, martyrologiami, trudnymi do policzenia konspiracjami oraz spiskami przykuwało uwage i oddziaływało na wyobraźnię. [...] Można bowiem od biedy wyobrazić sobie tę historię [historię wieku XIX - przyp. M.M.] bez Poznańskiego i Galicji, ale nie bez Królestwa i jego fabularnych dramatów! Bez martyrologii, poezji i narodowych cmentarzy. Nie przypadkiem o „stańczykach” czy „organicznikach” wie się dziś w Polsce o wiele mniej niż o powstaniach, o których słyszeli nawet najmniej douczeni rodacy. [...] Tradycję insurekcji, choć wystąpiła ona we wszystkich trzech zaborach, zawłaszczyło w zbiorowej pamięci

11 Zob. W. Łazuga, Kalkulować... Polacy na szczytach c. k. monarchii, Poznań 2013.

${ }^{12}$ Agenor Gołuchowski był w rządzie Johanna Rechberga (1859-1861) ministrem spraw wewnętrznych, a następnie faktycznym ministrem stanu, który wprowadził tzw. dyplom październikowy w 1860 r., federalizujący monarchię. Alfred Potocki oraz Kazimierz Badeni byli premierami. Pierwszy w latach 1870-1871, a drugi w okresie 1895-1897. 
Królestwo i skojarzyło ją z patriotyzmem. Z tradycją realizmu politycznego i pracy organicznej nie wiedziano, co zrobić ${ }^{13}$.

Ponieważ zainteresowania naukowe piszącego niniejszy artykuł ogniskują się wokół spraw galicyjskich, stąd właśnie Galicję uczynił przedmiotem analizy. Nie mniej ciekawe byłoby jednak spojrzenie na podręcznikowy obraz historii Polski z perspektywy zaboru pruskiego czy Śląska. Wówczas moglibyśmy uzyskać pełniejszy pogląd co do miejsca poszczególnych dzielnic zaborczych w ogólnopolskich narracjach podręcznikowych. One bowiem nolens volens zawsze odzwierciedlają aktualną politykę historyczną.

\section{Galicja w dziewiętnastowiecznych podręcznikach historii}

Pora przejść do analizy zdefiniowanego w tytule artykułu tematu. Choć literatura dotycząca podręczników galicyjskich jest już całkiem spora ${ }^{14}$, a podręcznikowy obraz Galicji był także przedmiotem artykułów naukowych $^{15}$, to problem wydaje się ciaggle in statu nascendi. Zamiarem piszącego jest więc dołożyć cegiełkę do tego dyskursu i pokazać, w jaki sposób

${ }_{13}$ W. Łazuga, Jedna czy trzy historie Polski?, [w:] Między polityką..., s. 8-10.

${ }_{14}$ Do najważniejszych pozycji należą: W. Zwolska, Podręczniki historii w gimnazjach galicyjskich w latach 1867-1914, „Zeszyty Naukowe Uniwersytetu Łódzkiego” 1972, seria I, z. 86, s. 27-45; J. Maternicki, Dydaktyka historii w Polsce 1773-1918, Warszawa 1974; S.I. Możdżeń, Podręczniki w galicyjskich szkotach średnich (1860-1885), „Acta Universitatis Wratislaviensis. Prace Pedagogiczne" 1975, nr 7, s. 33-60; M. Wierzbicka, Popularne podręczniki dziejów Polski w latach 1864-1914, [w:] Edukacja historyczna spoteczeństwa polskiego w XIX w. Zbiór studiów, red. J. Maternicki, Warszawa 1981, s. $355-$ -394; C. Majorek, Historia utylitarna i erudycyjna. Szkolna edukacja historyczna w Galicji (1772-1918), Warszawa 1990; M. Stinia, Podręczniki w gimnazjach galicyjskich $w$ latach 1860-1918, „Prace Komisji Historii Polskiej Akademii Umiejętności” 2004, t. 6, s. 5-39.

15 Zob.: M. Stinia, Obraz Galicji w gimnazjalnych i licealnych podręcznikach do nauczania historii, [w:] Polska-Europa-Świat w szkolnych podręcznikach historii. Torunskie Spotkania Dydaktyczne, t. V, red. S. Roszak, M. Strzelecka, A. Wieczorek, Toruń 2008, s. 162-171; E. Biesiadecka, Galicja w powojennych podręcznikach do nauczania historii (do 1956 roku), [w:] Wierny swemu dziedzictwu. Ksiega Jubileuszowa dedykowana Profesorowi Józefowi Pótćwiartkowi, red. ks. S. Nabywaniec, B. Lorens, ks. S. Zabraniak, Rzeszów 2010, s. 55-74. 
w kolejnych okresach historycznych (od XIX wieku po współczesność) podręczniki przedstawiały Galicję. Na co zwracały uwagę? Jakie wydarzenia eksponowały? Które postacie lansowały? Wreszcie, jak oceniały Galicję i jej dorobek? Odpowiedzi na te pytania pozwolą uchwycić sterującą warstwę teoretyczno-ideologiczną narracji poszczególnych podręczników ${ }^{16}$, za którą najczęściej ukrywa się obowiązująca w danym momencie polityka historyczna. Autorzy podręczników szkolnych podlegają bowiem wytycznym ministerialnych dokumentów programowych, które są zawsze odbiciem poglądów rządzących i ad hoc odzwierciedlają aktualny dyskurs władzy ${ }^{17}$.

$\mathrm{Na}$ początek przyjrzyjmy się podręcznikom najstarszym, powstałym przed I wojną światową. Przedstawiony w nich obraz Galicji, co oczywiste, musiał uwzględniać brak własnego państwa oraz wpisywać się w ówczesne uwarunkowania polityczne. Wynikały one z sytuacji powstałej po powstaniu styczniowym, którego bezpośrednim skutkiem był antypolski kurs w Królestwie, a pośrednim - germanizacyjna polityka rządu pruskiego. $\mathrm{Na}$ tym tle zupełnie inaczej jawiła się sytuacja w Galicji, której autonomia stanowiła wyraźny, pozytywny kontrast w stosunku do pozostałych zaborów.

Galicja uzyskała w latach sześćdziesiątych i na początku lat siedemdziesiątych XIX wieku względnie dobre warunki do rozwoju polskiej kultury, w tym oświaty. Koordynacją tej ostatniej zajęła się powołana w 1867 roku Rada Szkolna Krajowa (RSK), która działając na podstawie rozporządzenia wiedeńskiego Ministerstwa Wyznań i Oświaty w sprawie programów nauczania historii i geografii w gimnazjach z 12 VIII $1871 \mathrm{roku}^{18}$, wydała 12 I 1872 roku okólnik regulujący zasady nauczania „historii kraju rodzinnego” jako przedmiotu nadobowiązkowego w gimnazjach. Od samego początku przedmiot ten był pomyślany jako historia Polski i Rusi, gdyż obawiano się, aby nie stał się on polem konfliktu polsko-ukraińskiego. Jego fakultatywny charakter wzbudzał jednak opory polskich środowisk oświatowych

${ }^{16}$ Zob. J. Topolski, Jak się pisze i rozumie historię. Tajemnice narracji historycznej, Warszawa 1996, s. 108-109.

${ }_{17}$ Zob. M. Menz, Historia szkolna jako dyskurs wtadzy, „Środkowoeuropejskie Studia Polityczne" 2015, nr 4, s. 281-292.

${ }^{18}$ Verordnung des Ministers für Cultus und Unterricht vom 12 August 1871..., betreffend die Behandlung der Geschichte und Geographie an den Gymnasien, „Verordnungsblatt für Cultus und Unterricht" 1871, nr 45, s. 160-161. 
i politycznych, które domagały się uczynienia z „historii kraju rodzinnego” przedmiotu obowiązkowego. Stało się to ostatecznie w gimnazjach dopiero w 1909 roku $^{19}$.

Problemem, przed którym stanęli nauczyciele gimnazjalni prowadzący „historię kraju rodzinnego” był brak odpowiednich podręczników. RSK zalecała wprawdzie początkowo stosowanie książek ks. Teodora Kilińskiego (na poziomie niższym) ${ }^{20}$ oraz Henryka Schmitta (w gimnazjach wyższych) ${ }^{21}$, ale szybko się z tego pomysłu wycofała. Przeszkodą były względy naukowe i polityczne. Podręcznik Kilińskiego utrzymany był w tonie klerykalnym i nie uwzględniał wymogów nowoczesnej historiografii ${ }^{22}$. Natomiast Schmitt pisał w duchu Lelewela, co wywoływało krytykę ze strony Waleriana Kalinki i Józefa Szujskiego, twórców nowej szkoły historycznej, tzw. krakowskiej²3. Nie zmienia to faktu, że obaj autorzy poświęcili Galicji nieco miejsca w swoich podręcznikach.

Ks. Kiliński był bratankiem słynnego Jana i podobnie jak jego stryj zaangażował się w walkę narodowo-wyzwoleńczą, biorąc udział w powstaniu listopadowym. Doczekał się także insurekcji styczniowej, w trakcie

19 W szkołach realnych nauka historii kraju rodzinnego stała się obowiązkowa już w 1900 r., gdyż szkoły te podlegały jurysdykcji krajowej, a nie państwowej. Zob. C. Majorek, op. cit., s. 276. Zob. także: Plan nauki dla gimnazjów galicyjskich. Rozporządzenie c.k. Rady Szkolnej Krajowej z dnia 2 sierpnia 1909, Lwów 1909, s. 18-19.

${ }^{20}$ T. Kiliński, Dzieje narodu polskiego z tablica chronologiczna az do naszych czasów dla użytku mtodzieży, z dodatkiem geografii i mapy dawnej Polski przez X.T.K. utożone, Poznań 1858. Podręcznik miał 5 wydań (piąte w 1872 r.).

${ }^{21} \mathrm{H}$. Schmitt, Zdarzenia najważniejsze z przesztości narodu polskiego zestawit w potocznym opowiadaniu Henryk Schmitt, Lwów 1869.

${ }^{22}$ C. Majorek, op. cit., s. 319-320.

${ }^{23}$ Zob. J. Maternicki, Rewizjonizm szkoty krakowskiej, [w:] idem, Historia i życie narodu. Poglądy i postawy historyków polskich XIX i XX w., Rzeszów 2009, s. 132-182. Opis zmagań krakowskiej szkoły historycznej ze Schmittem przedstawił plastycznie jeszcze w XIX w. Walenty Ćwik. Odnotowując ostatnią pracę Schmitta, Rozbiór dzieta pt. „Dzieje Polski w zarysie" przez Michata Bobrzyńskiego (1882), autor takie uczynił podsumowanie: „Pracą tą zamknął Schmitt walkę z krakowską partią historyków polskich; bój, w którym przeciwnicy dźwigali wśród żywej palby, sztandar z napisem: "Precz z dawną szkołą historyczną, precz z Lelewelem, Moraczewskim, Schmittem«". W. Ćwik, Henryk Schmitt. Życiorys spisany na podstawie dokumentów i korespondencji, Lwów 1888, s. 213. 
której zmarł (18 IV 1863) 24. Narrację w podręczniku doprowadził do ustanowienia Królestwa Polskiego w 1815 roku, ale na końcu umieścił tablicę chronologiczną, w której w sposób rocznikarski uwzględnił najważniejsze wydarzenia porozbiorowe aż do lutego 1863 roku. Znalazły się tam więc także informacje dotyczące dziejów Krakowa i Galicji. Autor odnotował zatem: 1) zwycięstwo ks. Józefa Poniatowskiego nad Austrią w 1809 roku; 2) „rzeź w Galicji” oraz powstanie krakowskie z 1846 roku (tu wymienił Jana Tyssowskiego); 3) bombardowanie Lwowa w 1848 roku; 4) „ustawę konstytucyjną i wyborczą dla Galicji” z 1850 roku. Natomiast wydarzenia z przełomu lat pięćdziesiątych i sześćdziesiątych XIX wieku skoncentrowały uwagę Kilińskiego na Królestwie do tego stopnia, że o Galicji z tego okresu nie napisał już ani słowa.

Nieco więcej miejsca poświęcił jej natomiast Henryk Schmitt. Uczynił to w ostatniej, ósmej części swojego podręcznika, zatytułowanej Polska porozbiorowa (1796 do dni naszych). Zaprezentowany tam wykład dziejów Polski był skróconą wersją opublikowanych w 1868 roku Dziejów porozbiorowych (1795-1832)25. Uwaga autora skupiła się na Królestwie; Galicja jest w podręczniku zaledwie wzmiankowana. W odniesieniu do niej uwzględnił Schmitt następujące fakty: 1) włączenie Galicji w skład Księstwa Warszawskiego (1809); 2) istnienie Rzeczpospolitej Krakowskiej; 3) wyprawę Zaliwskiego z Galicji do Królestwa (1833); 4) zajęcie Krakowa przez wojska austriackie w 1836 roku; 5) powstanie krakowskie z 1846 roku. O tym ostatnim tak napisał:

$\mathrm{Na}$ podstawie bałamutnych sprawozdań o gotowości ludu wiejskiego zbudowano w Paryżu obszerny plan powstania, a dawszy doń hasło, przystąpiono (w lutym 1846) do czynu. Powstanie skończyło się najsmutniej w Galicji, gdy lud wiejski występując przeciw powstańcom powtórzył na mniejsze nieco rozmiary rzeź humańską. Władze rządowe

${ }^{24}$ Informacje biograficzne dotyczące Kilińskiego zob. E. Kierski, X. Kiliński Teodor Konstanty, w: Życiorysy zmartych cztonków Towarzystwa, „Roczniki Towarzystwa Przyjaciół Nauk Poznańskiego" 1871, t. 6, s. 346-349.

${ }^{25}$ H. Schmitt, Dzieje Polski XVIII i XIX wieku, t. 4: Dzieje porozbiorowe (1795-1832), Lwów 1868. 
wyparły się wszelkiego udziału w tej rzezi, o co powszechne winiło je przekonanie ${ }^{26}$

Schmitt surowo więc ocenił powstanie, akcentując przy tym swoją niechęć do jego właściwych sprawców, czyli emigracyjnych emisariuszy, wysyłających do Paryża (do kierownictwa Towarzystwa Demokratycznego Polskiego) „bałamutne sprawozdania o gotowości ludu wiejskiego” do powstania. Przytoczył też powszechną opinię, że za rzezią spowodowaną przez chłopów stały władze austriackie. Nie dał jednak własnej odpowiedzi czy tak było naprawdę, choć zastosowana w tekście sugestia de facto na to wskazywała.

Podsumowując podręcznik Schmitta, należy stwierdzić, że autor nie przedstawił w nim wyrazistego obrazu Galicji, traktując ją raczej epizodycznie. Nie wymienił żadnej postaci z jej historii (poza Tyssowskim) ani nie odnotował zmian konstytucyjnych, które zachodziły w latach sześćdziesiątych XIX wieku. Można zatem uznać, że dla Schmitta w momencie pisania podręcznika Galicja znajdowała się gdzieś na obrzeżach spraw polskich potraktował ją zatem peryferyjnie. Centrum stanowiły Warszawa oraz Królestwo i to na nich skupiła się zasadnicza uwaga autora.

Zupełnie inaczej Galicję potraktował krakowski profesor Anatol Lewicki. Jego Zarys historii Polski i krajów ruskich z nia potączonych ukazał się w Krakowie w 1884 roku i od razu uzyskał rekomendację RSK do nauki „historii kraju rodzinnego” dla poziomu gimnazjum wyższego ${ }^{27}$. Podręcznik ten nie uwzględniał jednak początkowo historii porozbiorowej (z wyjątkiem załączonych na końcu biogramów cesarzy austriackich, władających Galicją od 1772 r.), co spowodowało jego krytykę, której efektem były późniejsze przeróbki i uzupełnienia. I tak w wydaniu trzecim z 1897 roku autor uwzględnił dzieje porozbiorowe, które dopisał na krótko przed swoją śmiercią ${ }^{28}$. Późniejsze zmiany wprowadzili jeszcze: Henryk

${ }^{26}$ H. Schmitt, Zdarzenia najważniejsze..., s. 765.

${ }^{27}$ A. Lewicki, Zarys historii Polski i krajów ruskich z nią potączonych, Kraków 1884.

${ }^{28}$ A. Lewicki, Zarys historii polskiej aż do najnowszych czasów, wyd. większe 3 uzup. historią porozbiorową, Kraków 1897. 
Mościcki (w wydaniu z 1907 roku) ${ }^{29}$, Jan Friedberg (u progu niepodległości) ${ }^{30}$ oraz Józef Jasnowski i Franciszek Lenczowski (w trakcie II wojny światowej) ${ }^{31}$. Podręcznik był też dwukrotnie wznawiany jako reprint w czasach nam współczesnych: w latach 1999 i 2006 . W ostatnim wydaniu na okładce znalazła się następująca adnotacja: „Doskonała pomoc dla maturzystów i studentów"32 (sic!). Praca Lewickiego stanowi zatem pewnego rodzaju fenomen. Był najdłużej funkcjonującym podręcznikiem historii Polski i już z tego względu zasługuje na szczególną uwagę i dokładniejszą analizę.

Przyjrzyjmy się zatem co Lewicki napisał o Galicji. Autor poświęcił jej stosunkowo sporo miejsca w ostatniej części podręcznika, którą zatytułował Epoka czwarta (Czasy porozbiorowe od roku 1795). Już w pierwszym zdaniu stwierdził, że rozbiór był „bezprawiem i krzywdą”, gdyż wypływał $\mathrm{z}$ "przewrotnych pojęć politycznych, które wypielęgnował wiek osiemnasty, a który interes państwowy kładły przed sumieniem i prawem”. I zaraz po tym dodawał, że rozbiór był także „błędem politycznym”, gdyż „dozwolono Rosji, której właściwym zadaniem jest praca cywilizacyjna w Rosji, wzróść tak ogromnie w Europie" 33 .

Takie wprowadzenie było tożsame z poglądami stańczyków i krakowskiej szkoły historycznej ${ }^{34}$. Nie da się bowiem odczytać teoretyczno-ideologicznej warstwy narracji Lewickiego inaczej niż przez pryzmat stańczykowskiej polityki historycznej. Lewickiego zresztą do stańczyków in praxi

29 Zob. idem, Zarys historii polskiej aż do najnowszych czasów, wyd. 4, przejrzane i uzup. przez Henryka Mościckiego, Kraków 1907. Kolejne wydania ukazywały się do 1917 r. (wyd. 7).

${ }^{30}$ Zob. idem, Zarys historii Polski, oprac. i uzup. Jan Friedberg, wyd. 8 skr., Kraków 1919. Ostatnie przedwojenne wydanie szkolne (wyd. 13) ukazało się w latach 1928-1929.

${ }^{31}$ Idem, Zarys historii Polski, t. 1, wyd. nowe, popr. i uzup. przez J. Jasnowskiego i F. Lenczowskiego, Londyn 1943; J. Friedberg, Zarys historii Polski, t. 2, wyd. nowe, popr. i uzup. przez J. Jasnowskiego i F. Lenczowskiego, Londyn 1944.

${ }^{32}$ Zob.: A. Lewicki, J. Friedberg, Zarys historii Polski od zarania do roku 1925, Warszawa-Komorów 2006.

${ }^{3}$ A. Lewicki, Zarys historii polskiej..., wyd. 3, Kraków 1897, s. 368.

${ }^{34}$ Zob. np. J. Szujski, Kilka prawd z dziejów naszych. Ku rozważeniu w chwili obecnej, [w:] Dzieła Józefa Szujskiego. Wydanie zbiorowe, seria 3, t. 1: Pisma polityczne, Kraków 1885, s. 271-288. 
zaliczano. Analizując zatem jego podręcznik, musimy ten wzgląd mieć na uwadze.

Lewicki w swojej narracji dziejów porozbiorowych nie pomijał żadnej dzielnicy. Słusznie stwierdził bowiem, że historia Polski „rozpada się odtąd z konieczności na trzy działy: rosyjski, pruski i austriacki”. I konsekwentnie je przedstawiał.

Co do Galicji, najpierw wyjaśnił Lewicki genezę jej nazwy, a następnie scharakteryzował strukturę administracyjną i społeczną kraju. Potępił politykę germanizacyjną zaborcy oraz zantagonizowanie stosunków społecznych na wsi. Pisał:

Usunięto urzędników polskich, a sprowadzono na ich miejsce Niemców, którzy w swej żarliwości przyswojenia kraju nowemu państwu dopuszczali się wielorakich ucisków i nadużyć. Z największą nieufnością traktowano zwłaszcza szlachtę, na której do konstytucji 3 maja polegała siła narodu: dlatego wzięto w szczególniejszą opiekę chłopów, co znowu stało się powodem wielu krzywd szlachty i sprowadziło nieszczęsne rozdwojenie między włościanami a dziedzicami ${ }^{35}$.

Lewicki omówił następnie krótko reformy Marii Teresy i Józefa II, ale - co ciekawe - nie gloryfikował tych władców. Opisując np. ich dokonania oświatowe oraz tworzenie nowych szkół, stwierdził dosadnie: „Szkoły te miały nie tylko szerzyć oświatę w kraju, ale i niemczyznę; językiem wykładowym był język niemiecki”36. O sejmie i wydziale stanowym napisał z kolei, że „nie miały prawie żadnego znaczenia” ${ }^{37}$. Wyraźną sympatią darzył natomiast autor Leopolda II, który wedle jego słów „był Polakom przychylny"38.

Omawiając okres napoleoński, Lewicki uwzględnił wojnę z Austrią w 1809 roku i przyłączenie tzw. Galicji Zachodniej do Księstwa Warszawskiego. Decyzje kongresu wiedeńskiego w sprawach polskich nazwał „czwartym rozbiorem Polski”. W zakończeniu tej części stwierdził

\footnotetext{
35 A. Lewicki, Zarys historii polskiej..., wyd. 3, Kraków 1897, s. 374.

36 Ibidem, s. 375.

37 Ibidem, s. 376.

${ }^{38}$ Ibidem.
} 
z przekąsem, że: „Polsce w małej tylko części dotrzymano postanowień kongresu i obietnic monarchów. Straciła ona stanowczo samoistność swoją i rozdzielona pomiędzy trzy sąsiednie mocarstwa, zdana była odtąd na łaskę ich rządów"39.

W kolejnym rozdziale Lewicki przedstawił sytuację w latach 1815-1831 . Rozpoczął od wymienienia nowych dzielnic polskich powstałych po kongresie wiedeńskim: Rzeczpospolitej Krakowskiej, Galicji, Wielkiego Księstwa Poznańskiego, tzw. Krajów Zabranych, Królestwa Polskiego, a następnie omówił sytuację w każdej z nich. Przedstawiając Rzeczpospolitą Krakowską, skupił się na analizie jej ustroju w świetle konstytucji z 1815 i 1818 roku. Chwalił szczególnie tą drugą, podnosząc, że „była to konstytucja liberalna”, która „zapewniała możność rozwoju małemu państewku”40.

O wiele gorzej ocenił Lewicki sytuację panującą w Galicji. Napisał, że rządził w niej „wszechwładny minister ks. Metternich, największy wróg wszelkich konstytucyjnych wolności” ${ }^{41}$. Panujący w Galicji system określił dosadnie, że opierał się na trzech filarach: „nieufności, biurokracji i policji”².

Jak więc widzimy, ocena pierwszego okresu panowania austriackiego w Galicji była krytyczna. Nie lepiej oceniał też Lewicki okres późniejszy, skupiając uwagę na wydarzeniach z lat 1846-1848. O powstaniu 1846 roku napisał, że było „nieprzygotowane, źle obmyślane i niedołężnie wykonane”33. Główną winą za jego plan obarczył Ludwika Mierosławskiego, którego scharakteryzował jako człowieka „wielkiej ambicji i zarozumiałości [...], o którego talencie wojskowym miano przesadne wyobrażenie”44.

Sporo miejsca poświęcił też Lewicki rabacji galicyjskiej. Szukając jej źródeł, powtórzył zarzut, że to rząd austriacki, w celu zapewnienia sobie panowania w Galicji, wzniecał nieufność chłopów do szlachty, doprowadzając tym samym do krwawych wydarzeń. Opisując ich przebieg, chcąc

\footnotetext{
39 Ibidem, s. 415.

40 Ibidem, s. 417.

${ }^{41}$ Ibidem.

42 Ibidem, s. 418.

43 Ibidem, s. 476.

${ }^{44}$ Ibidem.
} 
uwypuklić grozę tragedii, nie szczędził Lewicki środków retorycznych. Oto przykład:

Baron Krieg postanowił użyć chłopów samych do stłumienia powstania, a znalazł w niektórych urzędnikach tak żarliwych wykonawców, że ich o umyślne podżeganie chłopów do rzezi szlachty posądzono. Smutną sławę zyskali sobie w tym względzie zwłaszcza starosta (Kreishauptmann) tarnowski, Breinl, za właściwego sprawcę rzezi uważany i podwładni mu urzędnicy [...]. Gdy więc powstańcy z okolic Tarnowa z powodu tej niechęci ludu przed umówionym terminem [...] wybrali się na Tarnów, aby go niespodzianie zaskoczyć, zostali przez porozstawiane warty chłopskie napadnięci i okropnie pomordowani lub pokaleczeni odwiezieni do cyrkułu w Tarnowie. Nie dosyć na tym, korzystając z dozwolonej swawoli, chłopi w tych stronach, pod naczelnym kierownictwem łotra Jakuba Szeli, chłopa ze Smarzowy, urządzili formalne wyprawy zbójeckie, „rabację” na dwory, mordując i rabując „ciarachów”, bez różnicy płci i wieku, wśród okrucieństw, na jakich opis wzdryga się serce ludzkie ${ }^{45}$.

Kto wie, czy Wyspiański, który się zapewne z podręcznika Lewickiego uczył, właśnie stamtąd nie zaczerpnął inspiracji do słynnej sceny z Wesela, w której pojawia się upiór Szeli. Nie ulega bowiem wątpliwości, że Lewicki był pierwszym autorem podręcznika, który rabację potraktował szerzej, oddziaływając na wyobraźnię czytelnika sugestywnym obrazem jej przedstawienia.

Równie plastycznie zostały ukazane wypadki krakowskie z 1846 roku. Lewicki pisze bowiem, że po opuszczeniu miasta przez żołnierzy austriackich Kraków „ujrzał się wolnym”, a Krakowanie, „mężczyźni i kobiety, współubiegali się w ofiarności”46. Ciepło wyraził się autor o Tyssowskim, stwierdzając, że było to „zacny i gorący patriota”, który jednak „nie miał zdolności na dyktatora w tak trudnych warunkach i ulegał zupełnie młodemu i niedoświadczonemu Dembowskiemu”“7 . Śmierć tego ostatniego przedstawił krakowski historyk w następujący sposób:

\footnotetext{
45 Ibidem, s. 477-478.

46 Ibidem, s. 478.

${ }^{47}$ Ibidem, s. 479.
} 
Równie smutny koniec miała procesja, wysłana [...] z Krakowa dla opamiętania rozszalałego chłopstwa, w której wzięło udział wielu księży i ludu, a na czele postępował z krzyżem w ręku w chłopskim ubraniu Dembowski. W Podgórzu napadli na nią znienacka żołnierze Collina, który tymczasem z Wadowic powrócił i rzucił się na bezbronnych. Jeden z pierwszych padł Dembowski, skłuty bagnetem (27 lutego $)^{48}$.

Skutkiem nieudanego powstania krakowskiego była, jak wiadomo, likwidacja Rzeczypospolitej Krakowskiej, którą Lewicki ocenił surowo. Było to złamanie postanowień kongresu wiedeńskiego i zniesienie „ostatniej resztki niepodległej Polski”’99. Czy na podobną niezależność opinii, np. w stosunku do przeszłości ZSRR, mógłby sobie pozwolić jakikolwiek autor podręcznika w okresie PRL-u? Pytanie jest oczywiście retoryczne. Rację miał wobec tego Henryk Wereszycki, który stwierdził, że „niewola zaboru austriackiego nie miała wyłącznie tylko skutków i stron ujemny$c{ }^{\prime \prime 50}$. A lojalizm stańczykowski nie przekraczał nigdy granic serwilizmu. Można było bowiem być i austriackim lojalistą, i polskim patriotą. Jedno drugiego nie wykluczało.

Wróćmy jednak do podręcznika. Po ukazaniu wydarzeń z 1846 roku autor dość szeroko scharakteryzował okres Wiosny Ludów. W odniesieniu do Galicji omówił najpierw żądania powstałych w Krakowie i we Lwowie komitetów narodowych, które domagały się autonomii, a następnie przedstawił sposób rozwiązania problemu włościańskiego (zniesienie pańszczyzny) oraz genezę problemu ukraińskiego (tzw. kwestii ruskiej). W obu sprawach krytycznie ocenił postępowanie władz austriackich. W przypadku kwestii chłopskiej podkreślił, że sejmy stanowe od dawna domagały się od władz centralnych, ,aby właścicielom ziemskim wolno było darować swoim włościanom pańszczyznę" ${ }^{11}$, ale rząd wolał to uczynić w formie aktu laski cesarskiej. W ten sposób odstręczał bowiem chłopów od szlachty i „zyski-

48 Ibidem.

49 Ibidem, s. 480.

${ }^{50} \mathrm{H}$. Wereszycki, Dzieje Galicji jako problem historyczny. Uwagi dyskusyjne, [w:] idem, Niewygasta przesztość. Refleksje i polemiki, Kraków 1987, s. 188.

${ }^{51}$ A. Lewicki, Zarys historii polskiej..., wyd. 3, Kraków 1897, s. 485. 
wał ich dla swoich widoków”52. Dla Lewickiego było to „postępowanie samowolne, albowiem pańszczyzna i grunta włościańskie nie były własnością rządu, lecz właścicieli ziemskich" "53. Konserwatyści krakowscy, do których Lewicki się z pewnością zaliczał, mieli zatem duże przywiązanie do zasad praworządności i konstytucjonalizmu. Ten liberalny aspekt ich poglądów nie zawsze jest należycie doceniany, a jest on przecież ważną spuścizną dziewiętnastowiecznej tradycji polskiego konserwatyzmu.

Problem ukraiński przedstawił Lewicki w sposób typowy dla ówczesnych polskich zapatrywań. Rusini powinni „dążyć do odzyskania bytu narodowego na podstawie historycznej, wspólnie i w porozumieniu z Polską", a nie przeciwko niej ${ }^{54}$. Dla Lewickiego kwestia ukraińska, podobnie jak włościańska, była wynikiem intrygi rządu austriackiego. To za jego bowiem sprawą powstała Rada Ruska, zwana świętojurską, której celem było „paraliżowanie dążności polskich”. Lewicki stawiał świętojurcom poważne zarzuty:

„stanęli $[\ldots]$ bezwarunkowo po stronie rządu, żądali podziału Galicji na część ruską i polską, domagali się nawet zatrzymania języka niemieckiego w szkołach i urzędach i rozpoczęli silną agitację po kraju, skutkiem czego powstało w narodzie niebezpieczne rozdarcie" ${ }^{\prime 5}$.

Lewicki nie rozumiał zatem skomplikowanego procesu narodotwórczego, jaki zachodził w drugiej połowie XIX wieku wśród Rusinów/ /Ukraińców. Odwoływał się do wspólnoty przeszłości, nie dostrzegając, że rodząca się wówczas historiografia ukraińska widziała tę przeszłość inaczej niż polska ${ }^{56}$. W omawianym okresie trudno zresztą byłoby znaleźć Polaka, który miałby szersze zrozumienie dla ukraińskich aspiracji narodowych,

52 Ibidem.

53 Ibidem.

54 Ibidem, s. 486.

55 Ibidem, s. 487.

${ }^{56}$ Jednym z twórców historiografii ukraińskiej był Mychajło Hruszewski. Zob. Ł. Adamski, Nacjonalista postępowy. Mychajto Hruszewski i jego poglady na Polskę i Polaków, Warszawa 2011. 
wolnych od polskiej kurateli. Lewicki prezentował zatem dominujący wówczas polski pogląd na tę sprawę.

Warto też zauważyć, że w opisie wydarzeń Wiosny Ludów autor w ogóle nie odnotował intronizacji cesarskiej Franciszka Józefa I (grudzień 1848), co stanowiło efekt jego autocenzury. Nie chciał przecież eksponować niewygodnego faktu, że to nowy cesarz odpowiadał za stłumienie ruchów wolnościowych w monarchii. Zdawkowo potraktował też pierwszą dekadę jego panowania (tzw. erę Bacha), stwierdzając, że wówczas „w Galicji nic się nie zmieniło na lepsze" 57 .

Dla Lewickiego Franciszek Józef I „narodził” się zatem dopiero w latach sześćdziesiątych XIX wieku. Wówczas, po dwóch nieszczęśliwych wojnach, w których Austria utraciła prowincje włoskie, cesarz uznał, że „tylko zadowolenie ludów stanowi siłę państwa" ${ }^{58}$. W związku z tym Franciszek Józef I zyskał miano „najmędrszego i najszlachetniejszego z monarchów Europy" "'; ; Austria zaś, wedle słów Lewickiego, zmuszona została porzucić politykę niemiecką i oddać się swojemu powołaniu, czyli „być ostoją dla ludów drobnych lub rozbitych, w jej skład wchodzących, i szerzycielką cywilizacji ku wschodowi"60.

W efekcie tych zmian Galicja skorzystała niewspółmiernie. Odkąd rządy przeszły w ręce Polaków - konstatował Lewicki - w kraju „przedtem przez rząd austriacki bardzo zaniedbanym, wzmógł się dobrobyt moralny i materialny i powstały instytucje, który dalszy jego wzrost poręczają"61. Wśród tych ostatnich autor wymienił następujące: uniwersytety i inne szkoły wyższe, Radę Szkolną Krajową (wraz z siecią szkolnictwa), Towarzystwo Sztuk Pięknych, Konserwatorium Muzyczne, Akademię Umiejętności oraz instytucję konserwatora zabytków (krakowskiego i lwowskiego). Autor podkreślił także dynamiczny rozwój infrastruktury w Galicji, tak ją charakteryzując:

\footnotetext{
${ }^{57}$ A. Lewicki, Zarys historii polskiej..., wyd. 3, Kraków 1897, s. 519.

${ }^{58}$ Ibidem.

59 Ibidem.

${ }^{60} \mathrm{Ibidem}, \mathrm{s.} 520$.

${ }^{61}$ Ibidem, s. 521.
} 
Dla ułatwienia komunikacji i handlu powstało od czasu autonomii w Galicji mnóstwo nowych i wybornych dróg i kolei żelaznych; powstały nowe kasy zaliczkowe i banki, wydane zostały ustawy dla podniesienia rolnictwa, chowu bydła, ochrony lasów, regulacji rzek; powstały nowe zakłady dobroczynne, szpitale itd. We wszystkich gałęziach życia narodowego widać postęp znaczny i niezaprzeczony" ${ }^{\text {"2 }}$.

W podręczniku autorstwa Lewickiego mamy więc dwa kontrastujące ze sobą obrazy Królestwa Galicji i Lodomerii. W pierwszym widzimy Galicję przedautonomiczną: uciemiężoną, zaniedbaną i wewnętrznie zantagonizowaną. Drugi z kolei jest zaprzeczeniem pierwszego - spoglądamy w nim na kraj szczęśliwy, dobrze rozwijający się i cieszący się wolnością. U Lewickiego - a to typowe dla narracji stańczykowskiej - ten drugi obraz kontrastuje także z sytuacją $\mathrm{w}$ dwóch pozostałych zaborach. Autor sporo bowiem miejsca poświęcił na wykazanie kierunku depolonizacyjnego na tych ziemiach. Na tym tle Galicja jawiła się jako swoiste eldorado i ostoja polskości.

W 1897 roku, a więc w momencie wydania książki, na czele rządu austriackiego stał hrabia Kazimierz Badeni, a w jego gabinecie zasiadało trzech innych Polaków ${ }^{63}$. Lewicki o tym wspomniał, choć nie wymienił żadnego nazwiska. Nie chciał bowiem pisać o politykach żyjących, co dobrze świadczy o jego warsztacie. Nie zmienia to jednak faktu, że polityczne dokonania Galicji oceniał pozytywnie. Zaliczył np. do mężów stanu następujących (nieżyjących już wtedy) polityków: Agenora Gołuchowskiego, Leona Sapiehę, Adama Potockiego i Mikołaja Zyblikiewicza. Ciekawe, że zabrakło w tym zestawieniu Alfreda Potockiego, który w latach 1870 1871 był premierem Austrii, a później wieloletnim namiestnikiem Galicji. Czyżby Potocki wydał się Lewickiemu zbyt lojalistyczny? Wysokie noty zyskali natomiast polscy parlamentarzyści, którzy jego zdaniem stanowili „jeden z najbardziej poważanych i wpływowych czynników w państwie"64.

${ }^{62}$ Ibidem, s. 522.

${ }^{63}$ Zob. W. Łazuga, „Rządy polskie” w Austrii. Gabinet Kazimierza hr. Badeniego 1895-1897, Poznań 1991.

${ }^{64}$ A. Lewicki, Zarys historii polskiej..., wyd. 3, Kraków 1897, s. 521. 
Ciekawe i przeczące tezie o rzekomym pesymizmie krakowskiej szkoły historycznej jest podsumowanie epoki porozbiorowej. Brzmi ono niemal identycznie jak stanowisko szkoły warszawskiej, reprezentowanej m.in. przez Tadeusza Korzona czy Władysława Smoleńskiego. Lewicki kończy bowiem swój wywód następująco:

[...] mimo okropnych klęsk, epoka ta świadczy o niespożytej żywotności narodu. Wady, na które cierpiała Rzeczpospolita Polska, a w szczególności wadliwość rządu i stosunków społecznych, naprawiła już po części konstytucja 3 maja; a epoka porozbiorowa, o ile to było możliwe, pracowała w myśl idei tej konstytucji [...]. Świetne czasy Księstwa Warszawskiego i Królestwa Kongresowego, kiedy Polacy sami się rządzili, jak nie mniej dzisiejszy rozwój Galicji [...] zadają kłam oszczerstwom, jakoby Polacy nie byli zdolni do samoistności ${ }^{65}$.

Czy w świetle tych oraz wcześniejszych słów można zarzucać podręcznikowi Lewickiego brak „ciepła narodowego"?66 Albo też mówić o pesymistycznym jego tonie? W moim przekonaniu nie ma po temu podstaw.

W zaborze austriackim funkcjonowało jeszcze kilka innych podręczników, które w sposobie przedstawiania Galicji prezentowały podobny dualizm, jaki widzieliśmy u Lewickiego. Do najważniejszych z nich należały książki: Karola Rawera, Bronisława i Gizeli Gebertów oraz Mariana Janellego i Julii Kisielewskiej ${ }^{67}$. Ich omówienie znajduje się w pracy Czesława Majorka, stąd nie ma potrzeby dłuższego zatrzymywania się przy nich $^{68}$. Swoją uwagę skupimy natomiast na podręczniku, który powstał

${ }^{65}$ Ibidem, s. 528.

66 Taki zarzut stawiał zaraz po I wojnie światowej na łamach „Muzeum” Andrzeja Wondaś: „Nie podnosił ten podręcznik uczuć narodowych polskich, gdyż był tak suchym przedstawieniem faktów historycznych, że na serca i uczucia młodzieży nie mógł oddziałać, brakło w nim tego ciepła narodowego, jakie powinno wiać z podręcznika historii Ojczyzny”. „Muzeum. Czasopismo Towarzystwa Nauczycieli Szkół Wyższych” 1920, z. 2, s. 103.

${ }^{67}$ Zob. K. Rawer, Dzieje ojczyste dla mtodzieży, cz. 1, Lwów 1893; cz. 2. Lwów 1895; B. Gebert. G. Gebertowa, Opowiadania z dziejów ojczystych dla klasy pierwszej szkót średnich, Lwów 1910; M. Janelli, J. Kisielewska, $Z$ dziejów ojczystych. Zbiór opowiadań dla mtodzieży klasy pierwszej szkót średnich, Lwów 1913.

${ }_{68}$ Zob. C. Majorek, op. cit., s. 321-328. 
pod koniec XIX wieku w Warszawie, a którego autorem był Władysław Smoleński.

Pierwsze wydanie Dziejów narodu polskiego ukazało się pod pseudonimem Władysława Grabieńskiego w latach $1897-1898^{69}$. Z podręcznika korzystano głównie w Królestwie, początkowo w ramach tzw. tajnego nauczania (w szkołach żeńskich), a następnie w latach 1905-1908 oficjalnie w szkolnictwie prywatnym ${ }^{70}$. Po 1908 roku, kiedy władze wróciły do polityki rusyfikacyjnej, Dzieje narodu polskiego ponownie stały się w Kongresówce podręcznikiem nielegalnym.

Smoleński Galicji poświęcił mniej miejsca niż Lewicki, rozbudował natomiast partie dotyczące Rzeczypospolitej Krakowskiej. Najpierw wyjaśnił genezę nazwy Królestwo Galicji i Lodomerii, a następnie przedstawił jego strukturę organizacyjną i scharakteryzował system rządów biurokratycznych. Zaznaczył, że ucisk austriacki zaraz po rozbiorach „dotkliwszy był, niż pruski, zarówno pod względem moralnym, jak materialnym"71. I dodawał: „Biurokracja, ograniczona a zuchwała, rekrutowała się przeważnie z wyrzutków społeczeństwa niemieckiego i czeskiego, siała w klasach niższych nienawiść ku wyższym, buntowała poddanych przeciwko panom, czeladź przeciwko majstrom, wtrącała się w stosunek dzieci do rodziców"72.

Omawiając okres napoleoński, nakreślił Smoleński różne fazy stosunków francusko-austriackich, akcentując zmagania ks. Józefa Poniatowskiego z armią Habsburgów, które przyniosły w 1809 roku włączenie Galicji Zachodniej do Księstwa Warszawskiego. Fakt ten skwitował w następujący sposób: „Wielka była radość narodu z powiększenia Księstwa i niemniejsza znowu ofiarność na utrzymanie jego bytu, pomimo najcięższych warunków

69 Pierwsze wydanie ukazało się w dwóch częściach w Krakowie. Zob. Wł. Grabieński, Dzieje narodu polskiego, cz. 1, Kraków 1897; idem, Dzieje narodu polskiego, cz. 2, Kraków 1898. W kolejnym roku ukazało się w Warszawie czteroczęściowe, bezimienne wydanie z przedmową W. Smoleńskiego, zostało ono jednak ocenzurowane. Zob. Dzieje narodu polskiego. Wyktad popularny na podstawie ostatnich badań naukowych z przedmowa Wtadystawa Smoleńskiego, cz. 1-4, Warszawa 1898.

${ }^{70}$ Zdaniem J. Maternickiego w tym okresie podręcznik Smoleńskiego cieszył się największym powodzeniem. Zob. J. Maternicki, Dydaktyka..., s. 177.

${ }^{71}$ W. Smoleński, Dzieje narodu polskiego..., cz. 4, s. 18.

${ }^{72}$ Ibidem. 
ekonomicznych"73. Smoleński w innym miejscu nie omieszkał zaznaczyć, że większą część Galicji podbiło wojsko polskie, a nie francuskie. Historyk nie darzył bowiem Napoleona szczególną estymą, wyrzucając mu, że nie chciał „wskrzeszenia Polski historycznej”74.

Przedstawiając okres ponapoleoński, najpierw omówił Smoleński postanowienia kongresu wiedeńskiego, a następnie skupił się na charakterystyce Rzeczypospolitej Krakowskiej. Podkreślił konstytucyjne zasady funkcjonowania tego państewka. Chwalił energię prezesa Senatu Rządzącego - Stanisława Wodzickiego, za to, że „podniósł miasto, zrujnowane podczas ostatnich wypadków politycznych, zaprowadził w nim ład wewnętrzny i ugruntował pomyślność ludności”75. I dodawał z uznaniem: „Dzięki samorządowi i uniwersytetowi, wyzwolonych spod wpływów niemieckich, Rzeczpospolita Krakowska miała możność rozwijania się w duchu narodowym i świecenia przykładem innym dzielnicom polskim"76.

Autor sporo miejsca poświęcił wypadkom 1846 roku, które doprowadziły do likwidacji Rzeczypospolitej Krakowskiej. Rzecz znamienna - jego narracja jest bardziej rozbudowana niż u Lewickiego, ale ogólna ocena wydarzeń oraz ich aktorów jest taka sama. Smoleński zatem identycznie ocenił Tyssowskiego, o którym napisał, że był więcej uzdolniony do rolnictwa niż do sprawowania władzy i kierowania walką. Stwierdził, że we wszystkim ulegał on „młodemu zapaleńcowi Edwardowi Dembowskiemu, który był istotnym dyktatorem"77. Jedyna różnica, która wystąpiła między oboma podręcznikami dotyczyła szczegółu śmierci Edwarda Dembowskiego. Według Smoleńskiego, co było prawdą, miał on zginąć od kuli, a nie od bagnetu, jak chciał Lewicki.

Autor Szkót historycznych w Polsce tak samo jak Lewicki przedstawił rabację galicyjską oraz jej przyczyny. Stwierdził bowiem, że system rządowy w Austrii „od lat kilkudziesięciu chłopów demoralizował i podburzał ich przeciwko dziedzicom"78. Chłopi zatem „faworyzowani przez władze [...],

\footnotetext{
73 Ibidem, s. 50.

74 Ibidem, s. 48.

75 Ibidem, s. 57.

76 Ibidem, s. 58.

77 Ibidem, s. 101

${ }^{78}$ Ibidem.
} 
poczytywali biurokrację za swą opiekunkę i dobrodziejkę"79. W konsekwencji „garstka nierozważnych porwała za broń”, gdyż uwierzyła, „iż powstańcy dążą do przywrócenia rządów polskich i dawnej niewoli ludów"

Smoleński, tak samo negatywnie jak Lewicki, charakteryzował Jakuba Szelę, przy czym wprowadził jeszcze do tekstu czterech innych przywódców chłopskich, którzy poszli za jego przykładem. Opis rzezi tarnowskiej jest u historyka warszawskiego przejmujący:

\begin{abstract}
„Poruszenie ludowe rozpoczęło się w Galicji zachodniej, w cyrkule tarnowskim. Jakub Szela, chłop ze Smarzowy, niegdyś podoficer austriac$\mathrm{ki}$, wypuszczony z kryminału przez starostę cyrkularnego, uformował z urlopników i zbrodniarzy hufiec w celu mordowania szlachty, przygotowującej się do powstania. Za jego przykładem poszli: Koryga i Stępak w cyrkule bochneńskim, Janocha w sandeckim, Bokola w przemyskim. Zabijali bezbronnych cepami, wyciągali z konających wnętrzności, zdzierali z czaszek skórę, rozmiażdżali głowy, nie oszczędzając kobiet i dzieci. [...] Padło z rąk ciemnego chłopstwa około 2 tysiące osób" ${ }^{\text {"1 }}$.
\end{abstract}

Szeroko przedstawił też Smoleński Wiosnę Ludów, której opis w odniesieniu do Galicji w zasadzie nie różni się od książki Lewickiego. Mamy zatem taką samą ocenę sposobu uwłaszczenia galicyjskich chłopów - jako aktu łaski cesarskiej, którego celem było dalsze antagonizowanie stosunków wiejskich. Mamy podobny opis bombardowania Krakowa oraz Lwowa. Jedyną różnicą jest pominięcie przez Smoleńskiego kwestii ukraińskiej.

Sytuację polityczną, która zapanowała po Wiośnie Ludów ocenił Smoleński następująco: „Po stłumieniu rewolucji wiedeńskiej zapanował w całej monarchii austriackiej, a więc i w Galicji, centralistyczny i despotyczny system ministra spraw wewnętrznych, Aleksandra Bacha, który wypowiedział wojnę prawom narodowym" ${ }^{82}$. Wymienił autor przy tej okazji Głuchowskiego, ale ocena tego polityka była negatywna: „chociaż Polak był narzędziem systemu bachowskiego" ${ }^{\prime 3}$.

\footnotetext{
79 Ibidem, s. 102.

${ }^{80}$ Ibidem.

${ }^{81}$ Ibidem.

${ }^{82}$ Ibidem, s. 110.

${ }^{83}$ Ibidem.
} 
Po obszernym przedstawieniu powstania styczniowego Smoleński wrócił jeszcze do Galicji, ale potraktował ją już po macoszemu. Krótko opisał przeobrażenia wewnętrzne w monarchii Habsburgów lat sześćdziesiątych XIX wieku, które przedstawił do konstytucji grudniowej 1867 roku, czyli do powstania monarchii dualistycznej. Niestety Smoleński pominął zupełnie Galicję okresu autonomicznego. Dopiero po I wojnie światowej dokonał krótkiego uzupełnienia w szóstym wydaniu podręcznika. Wówczas przedstawił organizacyjne ramy funkcjonowania Sejmu krajowego, samorządu terytorialnego oraz szkolnictwa. Wymienił też zagwarantowane przez konstytucję grudniową wolności oraz prawa jednostki. Swój wywód zakończył zdaniem: „Cesarz Franciszek Józef w przeciwieństwie do znienawidzonych władców rosyjskich i pruskich, cieszył się śród Polaków dużą popularnością" ${ }^{44}$. We wcześniejszych wydaniach podręcznika autor potraktował natomiast cesarza marginalnie.

Konkludując, Smoleński nie stworzył - jak to uczynił Lewicki - dwóch obrazów Galicji. Sporo napisał o niej z okresu drugiej połowy XVIII wieku i początku XIX, co było zrozumiałe ze względu na zainteresowania naukowe historyka, natomiast zbył milczeniem Galicję doby autonomicznej. Mamy zatem u niego sugestywny obraz Galicji rządzonej absolutystycznie, wedle zasady divide et impera. Natomiast nie mamy przeciwwagi w postaci obrazu Galicji szczęśliwej, korzystającej z uroków autonomii. Dlaczego? Trudno kategorycznie powiedzieć. Być może obawiał się Smoleński zarzutów środowisk liberalnych, że buduje taki sam przekaz jak konserwatywny Lewicki. A być może nie wypadało mu pisać o Galicji dobrze, gdyż mogłoby to wpisywać się w lojalistyczną ramę, której chciał uniknąc ${ }^{85}$. Stąd też aż tyle miejsca poświęcił Rzeczypospolitej Krakowskiej, którą przedstawił jako enklawę niepodległości, która przez nieco ponad 30 lat przypominała Europie o Polsce.

${ }^{84}$ W. Smoleński, Dzieje narodu polskiego, wyd. 6 uzupełnione, Warszawa 1921, s. 577.

85 Smoleński krytykował podręcznik Lewickiego za lojalizm. W 1899 r. w zbiorze wskazówek dla samouków pisał: „Podręcznik Lewickiego jest zastosowany do wymagań miejscowych, służyć może tylko ku nauce młodzieży galicyjskiej i ... pożytkowi Austrii”, cyt. za: J. Maternicki, Dydaktyka..., s. 362. 


\section{Galicja w podręcznikach duudziestolecia międzywojennego}

W okresie II Rzeczypospolitej nadal używano podręczników przedwojennych, zwłaszcza Lewickiego w wersji opracowanej przez Friedberga oraz Smoleńskiego (uzupełnionego przez niego samego). Jednak u progu niepodległości galicyjskie środowiska oświatowe, w tym autorzy podręczników, byli atakowani za swój wcześniejszy lojalizm i proaustriackość. Echa tej dyskusji, w której „prawdziwi” patrioci próbowali zdyskredytować ugodowców, są widoczne np. łamach „Kroniki Rady Szkolnej” za okres 1916-19196, „Muzeum” czy „Przeglądu Pedagogicznego”. W „Kronice” np. Fryderyk Zoll, który kierował RSK, tłumaczył lojalizm Polaków w Austrii tym, że był on warunkiem ich wpływu w państwie, co przekładało się na korzyści dla Galicji ${ }^{87}$. Argumentował to następująco:

Tą polityką zyskano wiele. I dzisiaj jej skutki okazują się choćby w tym, że b. Galicja dostarcza teraz całej Polsce urzędników i nauczycieli. Oczywiście kryła ona niebezpieczeństwa narodowe, ale wobec tego, iż walki orężne lat 1831 i 1863 o niepodległość Polski do zamierzonego celu nie doprowadzily, uważano, że w naszej sytuacji inna polityka nie była możliwą, a liczono [...], że społeczeństwo polskie uniknie złych skutków narodowych dzięki potędze swego patriotyzmu - i nie przeliczono się. [...] Młodzież nasza nie tylko umiała śpiewać „Boże coś Polskę" i „Z dymem pożarów”, ale czuła i myślała po polsku i czynami stwierdziła swe uczucia patriotyczne, jak to wykazały najnowsze wypadki wojenne, w których nasza młodzież szkolna tłumny wzięła udział ${ }^{88}$.

Nie wszystkich jednak taka argumentacja przekonywała. Przykładowo „Przegląd Pedagogiczny” donosił, że rektor Wyższej Szkoły Handlowej (dzisiejsza Szkoła Główna Handlowa) Julian Sujkowski podczas posiedzenia Koła Warszawskiego Towarzystwa Nauczycieli Szkół Wyższych w grudniu 1929 roku zarzucił szkole galicyjskiej, że tylko z pozoru była wolna, „w istocie zaś przeniknięta duchem austriackim" ${ }^{\prime 9}$. Z kolei recenzent pierwszego

\footnotetext{
${ }^{86}$ Kronika Rady Szkolnej za lata 1916/17, 1917/18, 1918/19, Lwów 1919.

87 Ibidem, s. 97.

${ }^{88}$ Ibidem, s. 98.

89 Upiory przesztości, „Przegląd Pedagogiczny” 1930, nr 2, s. 35.
} 
powojennego wydania podręcznika Lewickiego (w wersji Friedberga) na łamach „Muzeum” postulował, aby dokonać w nim zmiany obrazu Galicji autonomicznej, gdyż może negatywnie on wpływać na ocenę Polaków z tej dzielnicy. Twierdził, że nie powinno się pisać w podręczniku o ugodzie polsko-austriackiej, gdyż formalnie takiej nie było. Oto jak to ujmował:

Ugodę tę możnaby raczej upatrywać w programie warstw konserwatywnych $[\ldots]$ niż w stosunku narodu do sfer rządowych wiedeńskich; w żadnym jednak razie o ugodzie nie powinno być mowy w podręczniku szkolnym, aby młodzież nie piętnowała Polaków z Galicji jako zaprzańców, którzy dla kariery czy wygodnego życia wyrzekli się wielkich ideałów narodowych, wiążąc na zawsze swój los z losem Austriii ${ }^{90}$.

W podręcznikach, które ukazywały się w dwudziestoleciu międzywojennym (zwłaszcza po reformie Jędrzejewicza) widoczne jest echo tych dyskusji i próba zrzucenia z Galicji "grzechu” lojalizmu. Było to wynikiem nowej polityki historycznej odrodzonego państwa, które chciało budować swą tożsamość na tradycji walk narodowo-wyzwoleńczych, a nie na współpracy z zaborcą, nawet jeżeli przynosiła ona wymierne korzyści. Po przejęciu władzy przez sanację zasadniczy przekaz polityki historycznej w edukacji szkolnej skierowany został na Piłsudskiego, stającego się głównym depozytariuszem tej tradycji, która ostatecznie przyniosła Polsce niepodległość. W podręcznikowych obrazach Galicji zaczęto zatem nieco inaczej stawiać akcenty, choć trudno byłoby powiedzieć, że zerwano z dualizmem jej przedstawiania. Przyjrzyjmy się zatem kilku wybranym podręcznikom tamtej epoki.

Na początek trzy podręczniki, którego autorami byli nauczyciele galicyjscy: Kazimierz Krotoski, Adam Szelągowski i Czesław Nanke. Pierwszy z nich po wojnie przeniósł się do Poznania i tam zmarł. W 1918 roku opublikował Opowiadania $z$ dziejów powszechnych, średniowiecznych i nowożytnych ze szczególnym uwzględnieniem historii polskiej ${ }^{11}$, które nie były jed-

${ }^{0}$ A. Wondaś, Oceny i sprawozdania: Lewicki Anatol, Zarys historii Polski [recenzja], „Muzeum” 1912, nr 3-4, s. 223.

${ }^{91} \mathrm{~K}$. Krotoski, Opowiadania z dziejów powszechnych, średniowiecznych i nowożytnych ze szczególnym uwzględnieniem historii polskiej: dla szkót średnich, Kraków 1918. 
nak nową książką, tylko trzecim wydaniem (ze zmienionym tylko tytułem) wcześniejszego podręcznika do dziejów monarchii habsburskiej². Obraz Galicji w tym podręczniku jest w zasadzie taki sam jak u Lewickiego. Nie ma więc potrzeby jego omawiania, tym bardziej, że podręcznik należy w zasadzie do epoki minionej.

Kolejny autor (Adam Szelągowski) był przedstawicielem tzw. narodowej szkoły historycznej, krytycznej wobec szkoły krakowskiej ${ }^{93}$. W okresie I wojny światowej opracował własne podręczniki, które później przepracowywał i dostosowywał do powstających programów nauczania. Z punktu widzenia problematyki artykułu zajmiemy się tylko jednym z nich - Historiq nowoczesna, w której znalazły się wątki galicyjskie ${ }^{94}$.

Autor poświęcił Galicji sporo miejsca. Odnotował jej dzieje po upadku Rzeczypospolitej i w czasach napoleońskich, a następnie przeszedł do omówienia kolejnych okresów. I tak period po 1815 roku został przedstawiony jako czas reakcyjnych rządów metternichowskich. „Duch też Metternicha panował wszędzie: w sądach, urzędach i szkolnictwie" - napisał dosadnie ${ }^{95}$. Podkreślił antagonistyczne stosunki występujące na wsi oraz pogarszające się relacje Polaków z Rusinami. Powstanie krakowskie oraz rabację przedstawił podobnie, jak uczynili to Lewicki czy Smoleński. Za przywódcę powstania uznał Dembowskiego (miał zginąć „zakłuty bagnetami”"96), odnotował Tyssowskiego, wymienił Szelę. Tego ostatniego, inaczej niż poprzednicy, nie etykietował. Nie epatował też opisem zbrodni dokonanych przez chłopów, którym przewodził.

92 Idem, Opowiadania z dziejów monarchii austriacko-węgierskiej w związku z historią powszechną: dla klasy 3. szkót średnich, Kraków 1910 (wyd. 1), 1913 (wyd. 2).

${ }^{93}$ J. Maternicki, Polska dydaktyka historii 1918-1939. Materiaty i komentarze, Warszawa 1978, s. 57.

94 A. Szelągowski, Historia nowoczesna: rewolucja francuska, wiek XIX $i X X$ do wybuchu wojny światowej: 1788-1914, Warszawa 1918. Wydanie drugie (warszawsko-krakowskie) ukazało się w 1921 r. Wysoko ten podręcznik oceniła Hanna Pohoska: „Był to stanowczo pierwszy podręcznik powojenny, stojący na wysokości zadania”. H. Pohoska, Dydaktyka historii, Warszawa 1937, s. 300.

95 A. Szelągowski, op. cit., Warszawa-Kraków 1912, s. 194.

${ }^{96}$ Ibidem, s. 196. 
Wiosnę Ludów w Galicji potraktował Szelągowski zdawkowo - ważniejsze bowiem wydały mu się wypadki w Poznańskiem. Następnie scharakteryzował okres neoabsolutyzmu oraz przedstawił genezę autonomii. Przedstawiony przez niego obraz Galicji tego okresu różnił się nieco od wcześniejszych narracji. Szelągowski stwierdził bowiem, że w okresie rządów Bacha, kiedy w całej monarchii zapanował system centralistyczno-germanizacyjny, Galicję traktowano łagodniej. Wynikało to z niechęci Polaków do prowadzonej przez Rosję polityki panslawistycznej, która dla Austrii - ze względu na zamieszkujące ją narody słowiańskie - była szczególnie niebezpieczna. Autor podkreślił mądrość polityczną Agenora Gołuchowskiego, który potrafił tę rosyjską propagandę wykorzystać do walki z biurokracją niemiecką i przekonać monarchę do zmiany kierunku polityki wewnętrznej cesarstwa. Szelągowski z wielką estymą pisał o Gołuchowskim:

\begin{abstract}
administrator niezrównany, a jak się później okazało, czujny Polak; pozyskał też zupełnie zaufanie młodego cesarza, Franciszka Józefa. Jemu powierzył on misję pogodzenia rządu z ludami monarchii, po klęskach Solferina i Magenty, kiedy dawny system biurokratyczny doszczętnie zbankrutował. Gołuchowski wywiązał się z tego zadania, redagując tzw. dyplom październikowy [...]. Już na rok przedtem Gołuchowski, powołany na stanowisko ministra spraw wewnętrznych monarchii wydał rozporządzenie, zmierzające do spolszczenia administracji i sądownictwa w Galicji, a takie same podwaliny położył pod spolszczenie szkolnictwa [...]. Wprawdzie dyplom październikowy nie wszedł nigdy w życie [...], [ale] dzięki Gołuchowskiemu, społeczeństwo polskie w Galicji w tym okresie czasu już wchodziło na drogę pogodzenia się z monarchią habsburską na podstawie zasad samorządu (pierwszy sejm krajowy galicyjski, otwarty 15 kwietnia 1861$)^{97}$.
\end{abstract}

Jak więc widzimy, Szelaggowski uczynił z Gołuchowskiego ojca autonomii galicyjskiej. Jej obraz jest jednak nieco inny niż znane nam przedstawienia z wcześniejszych podręczników. Zasadnicza różnica polega na tym, że autor zbudował narrację adekwatną bardziej do podręcznika akademickiego niż do przekazu gimnazjalnego. Stąd jego obraz Galicji jest niejednoznaczny i pełen niuansów. Ogólnie autor ocenił ją jednak pozytywnie jako

97 Ibidem, s. 226-227. 
„zaczyn rozbudzenia narodowego"98. Nie omieszkał jednak dodać, że swoboda polityczna w Galicji była „bardzo względna i hamowana”9 . Również ocena rządów stańczyków, których Szelągowski najprawdopodobniej jako pierwszy autor wprowadził na łamy podręcznika, jest niejednoznaczna. $Z$ jednej strony chwalił ich za pracę organiczną, która przyniosła krajowi wielkie korzyści. Z drugiej zarzucił stronnictwu, że „zakonserwowało stosunki społeczne w Galicji”"100.

Analizie tych stosunków poświecił autor sporo miejsca, pokazując ich skomplikowany splot. Szeroko nakreślił rozwój ruchu ludowego i - nieco krócej - socjalistycznego. Zwrócił uwagę na słabość procesu industrializacyjnego w Galicji oraz na łatwość ulegania przez społeczeństwo procesowi proletaryzacji. Użył co prawda określenia „nędza Galicji”, ale tylko jako "opinii ostrzegawczej”, którą w latach osiemdziesiątych XIX wieku wyraził Stanisław Szczepanowski.

Sporo miejsca poświecił autor Kazimierzowi Badeniemu. Przedstawił jego dokonania jako szefa rządu austriackiego w zakresie reformy wyborczej (wprowadzenie piątej kurii) oraz ugody czesko-niemieckiej (projekt rozporządzenia językowego). Nie pominął także stosunków polsko-ukraińskich, które nakreślił jako skomplikowany węzeł gordyjski.

Ogólnie Szelągowski potraktował czytelnika (domniemanego ucznia $\left.^{101}\right)$ jako osobę intelektualnie dojrzałą, potrafiącą wyrobić sobie własne zdanie na poszczególne zagadnienia historyczne, w tym i na Galicję. Stąd nie stworzył jej jasnego obrazu (obrazów), a starał się pokazać jako problem. Dlatego Hanna Pohoska, zarzucając podręcznikowi Szelągowskiego przerost materiału, napisała równocześnie, że „zostanie bardzo ciekawą lekturą dla młodzieży” i być może znajdzie zastosowanie w inteligentnych i zdolnych klasach ${ }^{102}$.

Przyjrzyjmy się kolejnemu podręcznikowi, którego autorem był Czesław Nanke. Była to Historia nowożytna, której druga część obejmująca

\footnotetext{
98 Ibidem, s. 341.

99 Ibidem, s. 342.

100 Ibidem.

101 Słowa „uczeń” używam w dzisiejszym znaczeniu.

102 H. Pohoska, op. cit., s. 300-301.
} 
XIX wiek ukazała się w 1925 roku $^{103}$. Podręcznik jest o tyle reprezentatywny, że przystosowany został do ówczesnego programu nauczania i cieszył się poparciem władz ${ }^{104}$. W podręczniku tym widać już odbicie nowej polityki historycznej. Różnica widoczna jest przede wszystkim w sposobie sterowania narracją, która miała wykazywać rozwój ducha narodowego Polaków, mimo politycznej niewoli. Pamiętając, że podręcznik powstał w okresie, kiedy ster oświaty dzierżyli politycy narodowej demokracji, nie możemy się dziwić, że w pewnym stopniu odzwierciedlał jej politykę historyczną, czyli ideologię tzw. wychowania narodowego ${ }^{105}$. Przykładów jest wiele. Pierwszym może być wprowadzenie Żydów do narracji, których w dotychczasowych podręcznikowych obrazach Galicji pomijano. Zostali oni jednak przedstawieni tu negatywnie - jako czynnik kulturowo obcy, ulegający germanizacji. Nanke ukazał ich tak, jak to uczynił Roman Dmowski w Myślach nowoczesnego Polaka ${ }^{106}$. Oto przykład:

Zniszczenie [...] rodzimego żywiołu polskiego i ruskiego i przemiana Galicji na kraj „rdzennie” niemiecki było jedną z głównych wytycznych polityki rządu. [...] O ile niemczenie ludności polskiej i ruskiej nie udało się zupełnie, to istotnie akcja w stosunku do Żydów odniosła zamierzony skutek, czego dowodem, że dotychczas używają oni chętnie języka niemieckiego lub żargonu i lgną do kultury niemieckiej ${ }^{107}$.

Kolejnym przykładem potwierdzającym endecką ramę polityki historycznej, w którą wpisywał się podręcznik Nankego, jest akcentowanie przy

103 C. Nanke, Historia nowożytna: podręcznik dla klas wyższych szkót średnich; cz. 2: Od pierwszego rozbioru Polski i wybuchu rewolucji francuskiej do czasów najnowszych, Lwów-Warszawa 1925.

104 Ibidem, s. 301.

${ }^{105} \mathrm{Na}$ temat ideologii wychowania narodowego i państwowego, odzwierciedlonej w szkolnej edukacji historycznej, zob. więcej: M. Menz, Szkolna edukacja historyczna w Polsce w latach 1918-1939. Koncepcje-dyskusje-realizacje, [w:] Wspótczesna edukacja historyczna. Doświadczenia. Oczekiwania, red. J. Budzińska, J. Strykowska, Poznań 2015, s. 99-126.

106 R. Dmowski, Myśli nowoczesnego Polaka, Kraków 1904.

107 C. Nanke, Historia nowożytna: podręcznik dla klas wyższych szkót średnich; cz. 2: Od pierwszego rozbioru Polski i wybuchu rewolucji francuskiej do czasów najnowszych, Lwów-Warszawa 1931 (wyd. 6), s. 120-121. 
każdej okazji lojalizmu Polaków z Galicji jako cechy odróżniającej ich od rodaków z innych dzielnic. Przedstawiając np. wpływ powstania listopadowego na Galicję, autor nie omieszkał stwierdzić:

Powodów $[\ldots]$ do ostrzejszych wystąpień nie było, gdyż niezorganizowane i politycznie bierne społeczeństwo galicyjskie, okazując nawet pewną życzliwość dla powstania (np. przez zbieranie składek na utrzymanie uchodźców z Królestwa) nie przekroczyło jednak w niczym granic wiernopoddańczej lojalności względem Austrii' ${ }^{108}$.

Z kolei omawiając działalność spiskową na ziemiach polskich po powstaniu listopadowym autor stwierdził, że szczególnie w Galicji odegrała ona ważną narodowo rolę, ponieważ wytwarzał się już tam „typ Galicjanina”, tj. po polsku mówiącego Austriaka ${ }^{109}$. Sporo miejsca poświęcił Nanke powstaniu krakowskiemu, które uważał za przedwczesne, a Dembowskiego ocenił jako "gorącego patriotę", ale „nie mającego poczucia rzeczywistości” ${ }^{110}$. Rabację przedstawił w sposób już nam znany z wcześniejszych podręczników XIX wieku, a Szela znów zyskał miano największego zbrodniarza: „Zbójeckie te wyprawy pozostawały pod wodzą najgorszych wyrzutków społeczeństwa, a tych wszystkich prześcignął zbrodniczością Jakub Szela, chłop ze Smarzowy"111.

O autonomii w Galicji rozwodził się Nanke szeroko w rozdziale pt. Polska po powstaniu styczniowym. Przywołując stańczyków i zarzucając im uwarunkowany poglądami krakowskiej szkoły historycznej pesymizm (niewiarę w niepodległość i w twórcze siły narodu), stwierdził:

[stańczycy] straciwszy wszelką nadzieję - zwłaszcza po zwycięstwie Niemiec nad Francją - odzyskania niepodległości Polski, potępiali powstania, byli zasadniczymi przeciwnikami wszelkich ruchów konspiracyjnych i uważali lojalność wobec Austrii („Przy Tobie Najjaśniejszy

\footnotetext{
108 Ibidem, s. 151.

109 Ibidem, s. 163.

${ }^{110}$ Ibidem, s. 164.

111 Ibidem, s. 166.
} 
Panie, wiernie zawsze stać chcemy”) za podstawowy punkt swego programu $^{112}$.

Autor uznał jednak, że początkowo polityka ugodowa stańczyków przyniosła Galicji korzyści i przyczyniła się do umocnienia jej zdobyczy politycznych. W dłuższej jednak perspektywie był to program szkodliwy.

Nanke, co nie może dziwić, omawiając stronnictwo galicyjskie, z największym uznaniem wyrażał się o narodowej demokracji. Powtarzał tezy Romana Dmowskiego, że tylko stronnictwo narodowo-demokratyczne, $\mathrm{w}$ przeciwieństwie do innych, ogarniało całokształt spraw polskich (program wszechpolski) oraz że największą zasługą endecji było „obudzenie czujności społeczeństwa, widzącego dotychczas głównego swego wroga w Rosji, na niebezpieczeństwo pruskie"113. Wskazywanie na Niemców jako na głównego wroga polskości, charakterystyczne dla programu narodowej demokracji, ujawniało się podręczniku Nankego stosunkowo często. Np. przedstawiając zaognienie stosunków polsko-ukraińskich, których przejawem było zamordowanie przez ukraińskiego nacjonalistę namiestnika Andrzeja Potockiego, autor nie omieszkał uczynić następującej uwagi: „Istnieją silne poszlaki, że przeciwpolską działalność Ukraińców podsycał potajemnie, a nawet popierał materialnie rząd berliński"114.

Przykładów, które potwierdzają, że podręcznik Nankego realizował endecką politykę historyczną, jest znacznie więcej. Obraz Galicji nie został jednak przez to jakoś szczególnie wypaczony, tylko inaczej rozłożono w nim akcenty. Już nie konserwatyści (stańczycy) odgrywali w nim pierwszoplanową rolę, ale ci, którzy na sprawę polską patrzyli z perspektywy ponaddzielnicowej i ponadklasowej, czyli wszechpolskości. Nanke wpisał zatem swój obraz Galicji w teleologiczną ramę polityki historycznej endecji.

Lata trzydzieste XX wieku przyniosły zmianę polityki historycznej, która zyskała miano tzw. wychowania państwowego. Reforma programów dokonana przez ministra Janusza Jędrzejowicza została w pewnym stopniu tej polityce podporządkowana. Zasadniczym jej elementem był kult

\footnotetext{
112 Ibidem, s. 251.

113 Ibidem, s. 252-253.

114 Ibidem, s. 253.
} 
Piłsudskiego, a historię miano pokazywać w perspektywie państwowej. II Rzeczpospolita była bowiem państwem wielonarodowościowym i tylko instytucja państwa mogła zintegrować wspólnotę polityczną zogniskowaną wokół kategorii narodu obywatelskiego, a nie etnicznego. Takiej ramie polityki historycznej zostały podporządkowane podręczniki Tadeusza Bornholtza $^{115}$, Jana Dąbrowskiego ${ }^{116}$ oraz Wandy Moszczeńskiej i Haliny Mrozowskiej ${ }^{117}$. Zatrzymajmy się na chwilę przy dwóch ostatnich.

Zgodnie $\mathrm{z}$ założeniami programów lat trzydziestych XX wieku. $\mathrm{w}$ przedstawianiu historii ojczystej należało skupić się na eksponowaniu momentów pozytywnych. A takim nie była np. rabacja z 1846 roku. Rzecz znamienna, że zarówno Dąbrowski, jak i Moszczeńska, wraz z Mrozowską, w ogóle nie wymienili np. Szeli, a samą rabację pokazali tylko jako austriacką intrygę, która miała zapobiec wybuchowi powstania narodowego. Dąbrowski tak o niej pisał:

[...] władze austriackie, chcąc zniweczyć zaczynające się powstanie, podburzać zaczęły chłopów przeciw powstańcom. W niektórych okolicach nikczemna ta robota osiągnęła skutek: obałamuceni włościanie uderzyli nie tylko na powstańców, ale i na dwory, przelewając krew bratnią ${ }^{118}$.

Jeszcze oględniej potraktowały rabację Moszczeńska i Mrozowska, które nie tylko nie wymieniły Szeli, ale nawet nie użyły nazwy tego wydarzenia. Uczący się z ich podręcznika mogli o tym wydarzeniu przeczytać tylko tyle:

Do ruchu rewolucyjnego doszło najwcześniej na ziemiach polskich (w 1846 r.), choć plan powstania ogólnopolskiego zawiódł. Władze pruskie przeprowadziły bardzo liczne aresztowania w Poznańskiem, powstanie wybuchło więc tylko w Krakowie; przeciwko powstańcom wystąpiły

115 T. Bornholtz, Historia dla klas III gimnazjów, Warszawa 1935.

116 J. Dąbrowski, Historia dla klasy III gimnazjów, Lwów 1935.

117 W. Moszczeńska, H. Mrozowska, Podręcznik do historii na trzecią klase gimnazjalna, Lwów 1935.

118 J. Dąbrowski, op. cit., s. 148. 
nieuświadomione masy chłopskie, których niechęć do szlachty umiał podsycać i wyzyskać rząd wiedeński ${ }^{119}$.

Z podręczników napisanych zgodnie z wytycznymi reformy jedrzęjowiczowskiej uczeń nie dowiadywał się zatem wiele o rabacji. Nowa polityka historyczna miała być przecież „optymistyczna”, nie było więc potrzeby eksponowania bratobójczego wydarzenia z naszej przeszłości, które mogłoby ten przekaz zaburzać.

Z kolei obraz Galicji autonomicznej w ujęciu omawianych autorów to obraz polskiego Piemontu. Dąbrowski tak o tym pisał:

\begin{abstract}
Polacy galicyjscy walczyli [...] nie tylko o wprowadzenie w Austrii konstytucji, ale o możliwie szerokie prawa dla zaboru austriackiego. Pragnęli oni uzyskać dla Galicji autonomię, która pozwoliłaby uczynić z niej nie tylko ostoję polskiej kultury, lecz także podstawę prac nad odbudowaniem Polski, czyli „polski Piemont”, jak ją nazywano przez porównanie z Włochami ${ }^{120}$.
\end{abstract}

Moszczeńska i Mrozowska nie użyły tej nazwy expressis verbis, ale ich narracja skoncentrowała się na takim właśnie pokazaniu Galicji - jako miejsca, w którym Polacy przygotowują się do walki o niepodległość. Piętnowały zatem lojalizm, twierdząc, że jego przejawy „wzbudzały [...] niechęć znacznej części a często większości społeczeństwa”. I dodawały:

Na ogół żądano pracy u podstaw, tzn. pracy nad podniesieniem gospodarczym i kulturalnym kraju. Sprawy polityczne odsuwano na plan dalszy w przekonaniu, że na razie żadne w tej dziedzinie zmiany nie są możliwe. Pod koniec XIX w. ożywiły się jednak wśród społeczeństwa polskiego zainteresowania sprawami politycznymi"121.

Organizatorem tych spraw był oczywiście Piłsudski, którego postać ukazano hagiograficznie. To on okazał się wskrzesicielem tradycji bojowej, który wcielił w czyn ideę walki zbrojnej. „Kierunek tym wysiłkom - prze-

119 W. Moszczeńska, H. Mrozowska op. cit., s. 181.

${ }^{120}$ J. Dąbrowski, op. cit., s. 175.

121 W. Moszczeńska, H. Mrozowska, op. cit., s. 239. 
konywały autorki - nadała myśl Józefa Piłsudskiego, trwałość osiągniętych wysiłków zapewniła jego niezłomna wola"122.

Podobnie przedstawił Piłsudskiego Dąbrowski. Dla niego był on "najwybitniejszym spośród działaczy, przygotowujących walkę zbrojną" ${ }^{123}$, który „poprowadził przygotowane siły na pole walki”"124. Dąbrowski jednak, inaczej niż autorki, nie piętnował tak bardzo lojalizmu, dostrzegając realizm polityki Głuchowskiego, o którym wyrażał się z uznaniem: „Był to polityk trzeźwy, a stosunek Polaków do Austrii i cesarza oceniał bez złudzeń, wskazując na to, że Austria jest jedynym państwem zaborczym, w którym Polacy mogą liczyć na poszanowanie swych praw i swobodny rozwój narodowy" 125 .

Ogólnie Dąbrowski przedstawił bardziej szczegółowy obraz Galicji niż Moszczeńska i Mrozowska. Tak samo jednak jak one - co wynikało z polityki historycznej sanacji - uznał ją za etap do zasadniczego rozstrzygnięcia sprawy polskiej, czyli podjęcia walki zbrojnej o niepodległość. Z tej perspektywy obie narracje podporządkowane zostały ostatecznie budowaniu kultu Piłsudskiego. I nie uległo to już zmianie do wybuchu wojny.

\section{Galicja w podręcznikach Polski Ludowej}

Druga wojna światowa przyniosła upadek II Rzeczypospolitej, a w 1944 roku władzę przejęli komuniści, którzy swój mandat uzyskali z rąk Józefa Stalina. Początkowe działania władz skoncentrowały się na wyeliminowaniu opozycji politycznej oraz na zbudowaniu podstaw państwa totalitarnego. Zakończenie tego etapu nastąpiło w 1948 roku utworzeniem Polskiej Zjednoczonej Partii Robotniczej.

W kolejnych latach komuniści przeszli do ofensywy ideologicznej, a szkoła znalazła się na pierwszej linii frontu. Najpierw zmieniono ustrój szkolny, a następnie przystąpiono do wdrażania programów nauczania

\footnotetext{
122 Ibidem, s. 271.

123 J. Dąbrowski, op. cit., s. 198.

124 Ibidem, s. 201.

125 Ibidem, s. 175.
} 
opracowanych na podstawie założeń marksizmu ${ }^{126}$. W ich teleologicznej warstwie pierwszoplanową rolę miała odgrywać historia ${ }^{127}$.

Aby przysposobić nauczycieli-historyków do zadań indoktrynacyjnych zaczęto wydawać periodyk „Wiadomości Historyczne. Czasopismo dla nauczycieli”"128, którego zadaniem było przygotowanie kadr do nauczania historii w oparciu o założenia materializmu dialektycznego i historycznego $^{129}$. Materiał historyczny wtłoczono w marksistowską ramę periodyzacyjną, opartą na koncepcji pięciu formacji gospodarczo-społecznych: komuny pierwotnej, niewolnictwa, feudalizmu, kapitalizmu i socjalizmu ${ }^{130}$. Uczeń miał zyskać świadomość, że siłą sprawczą procesu dziejowego jest walka klas i wiedzieć, że to ona powoduje przechodzenie formacji niższych w wyższe. W ujęciu klasowym przedstawiono też Galicję. Przyjrzyjmy się zatem, jaki jej obraz budowano w podręcznikach Polski Ludowej.

Pierwszym podręcznikiem opracowanym według nowej koncepcji była Historia Polski Gryzeldy Missalowej i Janiny Schoenbrenner ${ }^{131}$. Missalowa pełniła wówczas także funkcję redaktorki „Wiadomości Historycznych” miała więc dodatkową okazję oddziaływania ideologicznego i tłumaczenia nauczycielom założeń dialektycznej metodologii historii. Przedstawiony w tym podręczniku obraz Galicji został wpisany w rewolucyjną ramę no-

${ }^{126}$ Nowy ustrój szkolny, oparty na 7-letniej szkole podstawowej i 4-letnim liceum, zaczął obowiązywać od roku szkolnego 1948/49. Nowe programy wprowadzono w roku kolejnym.

127 Zob. B. Jakubowska, Przeobrażenia w szkolnej edukacji historycznej $w$ Polsce $w$ latach 1944-1956, Warszawa 1986; M. Hoszowska, Praktyka nauczania historii $w$ Polsce 1944-1956, Rzeszów 2002; Z. Osiński, Nauczanie historii w szkotach podstawowych w Polsce w latach 1944-1989, Toruń 2006; A. Glimos-Nadgórska, Podręczniki do historii - 50 lat zmian, „Klio. Czasopismo poświęcone dziejom Polski i powszechnym” 2012, t. 21, z. 2, s. 3-30, DOI: KLIO.2012.018/1196.

${ }_{128}$ Pismo było wydawane od 1948 r. na zlecenie Ministerstwa Oświaty przy współpracy Polskiego Towarzystwa Historycznego, czym nawiązywało do przedwojennych Wiadomości Historyczno-Dydaktycznych. W latach 1953-1958 periodyk wychodził pod tytułem Historia i Nauka o Konstytucji. Czasopismo dla nauczycieli, po czym wrócił do pierwotnej nazwy. Czasopismo wychodzi do dzisiaj.

${ }^{129}$ Opierano się na stalinowskiej wykładni tej dialektyki. Zob. J. Stalin, O materializmie dialektycznym i historycznym, Warszawa 1949.

130 „Wiadomości Historyczne” 1949, nr 4, s. 5.

${ }^{131}$ G. Missalowa, J. Schoenbrenner, Historia Polski, Warszawa 1951. 
wej polityki historycznej, która narzuciła klasową perspektywę jej oglądu. $\mathrm{Z}$ tego punktu widzenia najważniejszym wydarzeniem całego XIX wieku dla Galicji i Krakowa było powstanie 1846 roku, które zostało przedstawione, zgodnie z opinią Marksa, jako pierwsza polska rewolucja, która wysunęła żądania socjalistyczne ${ }^{132}$.

Zupełnie nową pozycję w tym obrazie zajął Edward Dembowski, który zyskał miano rewolucjonisty i socjalisty polskiego. Autorki poświęciły mu sporo miejsca, przedstawiając jego życiorys hagiograficznie. Pisały, że cechowały go: bystry umysł, dar wymowy, talent, wielka pracowitość, skromność, uczynność i wrażliwość na krzywdy innych ${ }^{133}$. Jego poglądy polityczne przedstawiły następująco:

Szlachetne poglądy Dembowskiego to poglądy socjalistyczne. Dembowski zrozumiał, że nie tylko feudalizm, ale i kapitalizm to zły porządek; że są oparte na krzywdzie mas ludowych, na wyzysku ich pracy. Socjalista Dembowski wiedział, o co należy walczyć. Ale jeszcze nie rozumiał, jak skutecznie walczyć, żeby socjalizm zwyciężył. Wówczas jeszcze w Polsce nie było warunków dla zwycięstwa socjalizmu ${ }^{134}$.

Powstanie krakowskie zostało przedstawione jako rewolucja społeczna, którą szlachta i bogate mieszczaństwo postanowiło zdusić. Na przedstawiciela sił kontrrewolucyjnych „awansował” Tyssowski, któremu autorki zarzuciły następujące przewinienia: powołał do współpracy przeciwników rewolucji, nie dopuścił do uzbrojenia ludu, zabronił wzniesienia barykad. Jego plany miał jednak pokrzyżować Dembowski, który przybył do Krakowa „z oddziałem 200 uzbrojonych górników z Wieliczki”, został sekretarzem dyktatora i „przy pomocy ludu miejskiego zaczął nowe rządy w Krakowie” 135 . Niestety, „rewolucji podkopywanej działaniami wrogich sił nie udało się uratować" 136 .

\footnotetext{
132 Ibidem, s. 161.

133 Ibidem, s. 155.

134 Ibidem, s. 156.

135 Ibidem, s. 159.

136 Ibidem, s. 160.
} 
Dalsze wydarzenia zostały ukazane jako powstanie chłopskie, które wybuchło przeciwko szlachcie. Chłopi z Szelą nie byli już ukazywani w sposób znany nam z dotychczasowych podręczników, tylko stali się mścicielami „swoich wiekowych krzywd” 137 . Nie wiedzieli oni jednak, że „rewolucjoniści krakowscy z Edwardem Dembowskim na czele występowali w obronie ich sprawy" i dali się zwieść podstępnym urzędnikom austriackim, którzy tłumaczyli im, „że powstanie krakowskie to wojna „panów”, że zniesienie poddaństwa chłopi mogą oczekiwać od cesarza w Wiedniu”"138.

Autorki opisały jeszcze śmierć Dembowskiego, który próbował przekonać chłopów, że "rewolucja krakowska niesie im wolność i ziemię”, ale niestety zginął od kuli, kiedy urządził uroczystą procesję. Po jego śmierci powstanie upadło, gdyż zostało „zdradzone” przez szlachtę i burżuazję, a Tyssowski bez walki opuścił Kraków i złożył broń na granicy pruskiej ${ }^{139}$.

Galicja drugiej połowy XIX wieku została potraktowana bardzo zdawkowo. Autorki ukazały ją jako miejsce nędzy chłopskiej, kontrastującej z hulaszczym i wystawnym życiem szlachty ${ }^{140}$. Autonomię - bez użycia zresztą tej nazwy - autorki tak charakteryzowały:

\footnotetext{
Po przegranej wojnie z Prusami Austria musiała zgodzić się na ustępstwa. Polacy w Galicji otrzymali je także. Zarząd krajem przekazał rząd austriacki reakcyjnym polskim magnatom i polskiej szlachcie. Gnębili oni chłopów. Prześladowali Ukraińców. Zwalczali zwłaszcza ukraiński ruch narodowy. Kraj utrzymywali w nędzy i zastoju. Do władz wiedeńskich odnosili się wręcz służalczo. Potępiali powstania narodowe i walki społeczne ${ }^{141}$.
}

Nie ulega wątpliwości, że obraz Galicji w ujęciu Missalowej i Schoenbrenner został całkowicie przekłamany i przedstawiony w konwencji typowej dla okresu stalinowskiego. Podręcznik ten był właściwie przeznaczony dla szkoły podstawowej, ale w praktyce - z powodu braku innego wówczas marksistowskiego ujęcia historii Polski - wykorzystywano go tak-

\footnotetext{
137 Ibidem.

${ }^{138}$ Ibidem.

139 Ibidem, s. 160-161.

140 Ibidem, s. 193

141 Ibidem, s. 194.
} 
że w liceach. Natomiast podręcznikami przeznaczonymi tylko dla uczniów szkół średnich były książki zredagowane przez Stefana Kieniewicza ${ }^{142}$ i Żannę Kormanową ${ }^{143}$, a następnie dwa kolejne podręczniki, z których autorem pierwszego był Henryk Sędziwy ${ }^{144}$, a drugi zredagował Tadeusz Łepkowski ${ }^{145}$. Ostatnimi PRL-owskimi podręcznikami, z których licealiści poznawali wiek XIX, były prace Adama Galosa, Józefa Gierowskiego i Józefa Leszczyńskiego ${ }^{146}$ oraz Romana Wapińskiego ${ }^{147}$. Przyjrzyjmy się krótko tym podręcznikom.

W podręczniku zredagowanym przez Kieniewicza, a obejmującym okres do 1864 roku, mamy przedstawioną sytuację w zaborze austriackim zaraz po rozbiorach i w okresie napoleońskim. Autorem tej części był Tadeusz Mencwel, który wyjaśnił genezę nazwy „Galicja” oraz scharakteryzował reformy wprowadzone przez Marię Teresę i Józefa II. Jego zdaniem reformy te „nie zmierzały do likwidacji feudalizmu, ale do jego wzmocnienia poprzez zniesienie bardziej krzyczących nadużyć”. Tę nielogiczną tezę autor uzasadniał w ten sposób, że „władza państwowa miała ograniczyć ucisk chłopów przez pana wsi, ażeby zwiększyć w zamian bezpośrednią eksploatację tegoż chłopa przez państwo" 148 .

Okres 1815-1845 przedstawił w podręczniku Witold Łukaszewicz. Galicję pokazał jako miejsce zastoju gospodarczego i ucisku polskiego oraz ukraińskiego chłopa ${ }^{149}$. Autor wspomniał jednak o założeniu Ossolineum we Lwowie, które stało się „poważnym ogniskiem w krzewieniu kultury

142 S. Kieniewicz, T. Łepkowski, W. Łukaszewicz, T. Mencel, Historia Polski 1795-1864, red. S. Kieniewicz, Warszawa 1956.

${ }_{143}$ Historia Polski 1864-1945. Materiaty do nauczania w klasie XI, red. Ż. Kormanowa, Warszawa 1952.

${ }^{144}$ H. Sędziwy, Historia dla klasy XI. Część I: od Komuny Paryskiej do końca I wojny światowej, Warszawa 1960.

${ }^{145}$ H. Katz, T. Łepkowski, H. Sędziwy, Historia dla klasy X, Warszawa 1966.

146 A. Galos, J. Gierowski, J. Leszczyński, Historia dla klasy 3 liceum ogólnoksztatcącego. Część pierwsza, Warszawa 1971 (korzystam z wydania 11. z 1981 roku; ostanie wydanie w 1990 r.).

147 R. Wapiński, Historia dla klasy 3 liceum ogólnoksztatcącego oraz klasy 3 technikum. Częśc druga, Warszawa 1971 (ostatnie wydanie w 1981 r.).

148 S. Kieniewicz, T. Łepkowski, W. Łukszewicz, T. Mencwel, Historia.., s. 8-9.

149 Ibidem, s. 92. 
i nauki polskiej”"150. Omówił także krótko dokonania galicyjskich organiczników tego okresu, wymieniając przy tym Leona Sapiehę jako głównego inicjatora i propagatora tej idei w Galicji. Ocena tych dokonań była jednak co najmniej powściągliwa: „[...] wszystkie te prace cechowała lękliwość i połowiczność. Szlachta galicyjska bała się dotykać podstawowej kwestii społecznej, tj. reformy stosunków pańszczyźnianych"151.

Łukaszewicz omówił także funkcjonowanie Rzeczypospolitej Krakowskiej, ale powstanie 1846 roku oraz okres Wiosny Ludów został już napisany przez Kieniewicza. Jego sposób przedstawienia tego pierwszego wydarzenia jest podobny do ujęcia Missalowej i Schoenbrenner. Kieniewicz przedstawia zatem powstanie krakowskie jako próbę rewolucji agrarnej i, podobnie jak one, za głównego jej rzecznika uważa Dembowskiego. Jedyna różnica jest taka, że dla Kieniewicza nie jest on socjalistą tylko rewolucyjnym demokratą.

Podobnie przedstawił autor rabację galicyjską (nie używając oczywiście takiej nazwy). W jego narracji była ona „powstaniem chłopów galicyjskich”, które miało charakter klasowy i zmierzało do „obalenia poddaństwa i pańszczyzny”, uderzając przy tym nie tylko w szlachtę, „ale i w feudalną Austrię"152. Autor podkreślił jednak, że chłopi „dali się użyć za narzędzie biurokracji austriackiej i przyczynili się do upadku powstania krakowskiego" ${ }^{\prime 153}$. Winę za taki stan rzeczy widział w niedostatecznym ich uświadomieniu przez rewolucyjnych demokratów.

Kieniewicz, w porównaniu do Historii Polski Missalowej i Schoenbrenner, rozbudował jeszcze pozytywny wizerunek Szeli. Przedstawił go jako „przywódcę oporu chłopskiego”, który okazał się dobrym organizatorem, umiejącym zdobyć zaufanie chłopów i potrafiącym negocjować z władzami austriackimi w celu uzyskania „wydatniejszej obniżki pańszczyzny lub jej zamiany na czynsz" ${ }^{154}$.

\footnotetext{
${ }^{150}$ Ibidem.

151 Ibidem, s. 93.

152 Ibidem, s. 130.

153 Ibidem, s. 133.

154 Ibidem, s. 132.
} 
Kieniewicz omówił także Wiosnę Ludów, nie pomijając przy tym Galicji. Przedstawiając jej przebieg mocno zaakcentował kwestię ukraińską, którą ujmował w następujący sposób:

Rok 1848 otworzył możliwości rozwoju także przed ukraińską ludnością Galicji. Polska szlachta i burżuazja traktowały Galicję jako kraj czysto polski i odmawiały Ukraińcom odrębnych praw narodowych. Część ukraińskich działaczy szukała przeciw Polakom oparcia u władz austriackich: w ten sposób szowinizm polskich klas posiadających szedł na rękę obozowi reakcji ${ }^{155}$.

Autor dodał, że tylko „posłowie chłopscy obu narodowości bronili zgodnie wspólnych interesów” 156 .

Okres autonomii galicyjskiej został przedstawiony już w kolejnym podręczniku, który zredagowała czołowa propagatorka komunistycznej wykładni historii w polskim szkolnictwie okresu stalinowskiego - Żanna Kormanowa. W podręczniku tym mamy szeroko przedstawione w ujęciu klasowym stosunki społeczno-gospodarcze, natomiast swobody autonomiczne są pokazane jak w krzywym zwierciadle. Autorka twierdziła bowiem, że autonomia „oddana w ręce reakcyjnego obszarnictwa, stała się ze swej strony jeszcze jednym czynnikiem hamującym rozwój gospodarczy tej dzielnicy” ${ }^{157}$. W innym miejscu dodała, że „polskie klasy posiadające” autonomię oraz swobody narodowe wyzyskały „do stworzenia pozorów przesłaniających przed masami ludowymi ich służalczą, reakcyjną i antynarodową politykę"158.

Najwięcej miejsca poświęcono na ukazanie rozwoju ruchu robotniczego i ludowego. Stańczycy zyskali natomiast miano zwolenników polityki trójlojalizmu. Kuriozalne, ale i typowe dla całokształtu narracji w tym podręczniku są podsumowania i ocena okresu autonomicznego. Oto pierwsze z takich uogólnień: „Galicja w składzie monarchii austro-węgierskiej pozostała krajem magnackich latyfundiów i chłopskiej biedy, ideologicznego

\footnotetext{
155 Ibidem, s. 144.

156 Ibidem.

157 Ż. Kormanowa, op. cit., s. 32.

158 Ibidem, s. 79.
} 
monopolu Kościoła i analfabetyzmu"159. I drugie, które kieruje już uwagę ucznia na „właściwy” odbiór II Rzeczypospolitej: „Tak więc dla polskiej burżuazji, obszarników i burżuazyjno-szlacheckiej inteligencji stanowiła Galicja niejako przedsmak tego, czym mogłoby być dla nich własne burżuazyjne państwo polskie" 160 .

Podręcznik Kormanowej zastąpiła na początku lat sześćdziesiątych XX wieku książka Sędziwego, która zawierała obraz Galicji autonomicznej. Natomiast dopiero w 1966 roku ukazał się nowy podręcznik zredagowany przez Tadeusza Łepkowskiego, który wyparł omówiony wyżej podręcznik Kieniewicza. Okres autonomii przedstawiony przez Sędziwego został uwolniony od stalinowskiej ramy i przedstawiony bardziej obiektywnie. Autor szeroko przedstawił instytucjonalne jej uwarunkowania oraz omówił osiągnięcia w dziedzinie kultury i oświaty. Podkreślił np. zasługi Rady Szkolnej Krajowej w zakresie zwalczania analfabetyzmu. Uznał rolę Akademii Umiejętności w Krakowie dla integracji polskiej nauki. Bardziej stereotypowo natomiast przedstawił stosunki społeczne (antagonizm klasowy) i sytuację gospodarczą w Galicji (zacofanie) oraz stańczyków, których program polityczny sprowadził do koncepcji trójlojalizmu i oskarżył ich, że byli przeciwnikami oświaty ludowej. Sporo miejsca zajęło autorowi wykazanie różnic pomiędzy stańczykowską wersją pracy organicznej a realizacją tego programu w innych zaborach. Konkluzja była następująca:

Stańczycy galicyjscy, którzy występowali w roli ideologów pracy organicznej, byli ugodowcami-lojalistami, programowo wstrzymywali rozwój gospodarczy i społeczny kraju w kierunku kapitalizmu. Z organicznikami innych dzielnic łączył ich tylko negatywny stosunek do ruchów niepodległościowych ${ }^{161}$.

Ogólnie jednak należy uznać podręcznik Sędziwego - przynajmniej $\mathrm{w}$ stosunku do przedstawionego w nim obrazu Galicji po powstaniu styczniowym - za umiarkowanie obiektywny, choć nie wolny oczywiście od marksistowskiego ujęcia. Galicja i Kraków okresu wcześniejszego

159 Ibidem.

160 Ibidem, s. 240.

161 H. Sędziwy, op. cit., s. 74. 
znalazły natomiast szerokie miejsce na kartach pracy zredagowanej przez Łepkowskiego, którego podręcznik funkcjonował w polskich liceach stosunkowo krótko, bo tylko pół dekady. Mamy w nim zatem pokazane kolejne okresy Galicji, od rozbiorów poprzez okres napoleoński i czasy pokongresowe aż do powstania styczniowego. Autor sporo miejsca poświęcił Rzeczypospolitej Krakowskiej i powstaniu 1846 roku.

Podobnie jak Missalowa i Schoenbrenner najważniejszą postacią okresu 1815-1846 autor uczynił Dembowskiego. Uznał go za jednego z najwybitniejszych polskich rewolucjonistów, człowieka o ogromnych zdolnościach, odznaczającego się pracowitością i energią ${ }^{162}$. O jego dorobku ideowo-politycznym napisał:

Myśl Dembowskiego to największe wówczas w Polsce osiągnięcie postępowej teorii społecznej. Materialista i ateista, podkreślał, że w życiu trwa ciągła walka nowego ze starym, że rozwój społeczny zmierza ku komunizmowi. Dembowski, co trzeba podkreślić, komunizm pojmował jako ustrój sprawiedliwości, lecz - rzecz jasna - nie rozumiał go tak, jak czynili to marksiści w II połowie XIX w. ${ }^{163}$

Także ocena Szeli jest w podręczniku Łepkowskiego wręcz apologetyczna. Charakteryzując tę postać, autor poszedł jeszcze dalej niż Kieniewicz. Uznał go za jednego z najwybitniejszych przywódców chłopskich, który w sporach gromady z dziedzicem zyskał popularność i zaufanie wsi, a w 1846 roku walczył z wyzyskiem, ale nie był bynajmniej sojusznikiem austriackiej władzy. Łepkowski tak o nim pisał:

Ludowy przywódca zaprowadził straże wiejskie i lokalne władze, pilnowat, by nie wychodzono na pańskie, karał jakikolwiek brak dyscypliny. Nie wolno było nawet chłopom wywozić drzewa z lasu bez specjalnej przepustki, a pijaństwo ukrócono, gdyż Szela opieczętował zapasy wódki w gorzelniach na podległym terenie ${ }^{164}$.

${ }^{162}$ H. Katz, T. Łepkowski, H. Sędziwy, Historia ...., s. 114.

163 Ibidem, s. 115.

164 Ibidem, s. 131. 
Tak więc uczeń na podstawie takiej narracji mógł wyrobić sobie jak najlepsze zdanie o Szeli. Zbrodnie tego przywódcy Łepkowski bowiem przemilczał.

I na koniec dwa ostatnie podręczniki, z których młodzież uczyła się o Galicji w ostatnich dwóch dekadach PRL-u. W publikacji Galosa, Gierowskiego i Leszczyńskiego, tak jak w większości omówionych podręczników, zostały przedstawione wszystkie najważniejsze etapy z dziejów Galicji i Krakowa do 1864 roku (od rozbiorów do upadku powstania styczniowego). W podręczniku, mimo że nie jest on oczywiście wolny od ujęcia marksistowskiego, widać już jednak bardziej liberalnego ducha lat siedemdziesiątych XX wieku. Ogólnie jednak ocena czy to Dembowskiego, czy Szeli nie zmieniła się. Autorzy poświęcili pierwszemu jednak znacznie mniej miejsca niż Łepkowski i - co ważne - ukazując jego postać pozytywnie, nie uczynili tego w sposób hagiograficzny.

Z kolei Szela został przedstawiony jako przywódca „ruchu chłopskiego” (autorzy użyli już nazwy „rabacja”) ${ }^{165}$, który „po rozpoczęciu wystąpień chłopskich sam prowadził włościan na najbliższe dwory". Autorzy z uwagi na cenzurę chcieli zapewne uniknąć krwawego opisu rabacji, stąd uciekali się do eufemizmów. Oto przykład: „W ciągu jednego dnia potrafił [Szela] rozgromić kilkanaście dworów. Nie udawał, że wypełnia rozkazy cesarskie, ale głosił: "Żadnych panów nie potrzebujemy, sami sobie damy radę«"166.

I wreszcie ostatni podręcznik, którego autorem był Roman Wapiński. Genezę autonomii ukazał on w kontekście walki obozu konserwatywno-ugodowego (na czele z Gołuchowskim, który tym samym „powrócił” na łamy podręczników) z liberalno-mieszczańskim (na czele z Franciszkiem Smolka) ${ }^{167}$, z którego zwycięsko wyszedł ten pierwszy, gdyż miał poparcie Wiednia. Nie zmieniła się natomiast ocena stańczyków w stosunku do wcześniejszych podręczników PRL-u. Nadal byli oni przedstawiani jako ideolodzy trójlojalizmu i siewcy pesymizmu narodowego. Wapiński tak o tym pisał:

\footnotetext{
165 A. Galos, J. Gierowski, J. Leszczyński, op. cit., s. 116.

166 Ibidem, s. 116.

167 R. Wapiński, op. cit., s. 20-21.
} 
Ta ideologia lojalizmu i pesymizmu narodowego stanowić miała odtąd uzasadnienie programu rządów konserwatywnego ziemiaństwa w autonomicznej Galicji. Pozwalała ona między innymi prowadzić politykę utrzymującą przebrzmiałą już strukturę stanową. Dla jej realizacji stańczycy bardzo umiejętnie wykorzystywali istniejące w Galicji możliwości rozwoju życia narodowego, przypisując sobie całość zasług w ich uzyskaniu $^{168}$.

Wapiński, choć uwzględnił także dodatnią stronę autonomii galicyjskiej, przejawiającą się przede wszystkim w rozwoju instytucji kultury polskiej, w wielu aspektach jej oceny pozostał na tych samych pozycjach, które widzieliśmy w podręcznikach wcześniejszych. Ogólnie zatem można stwierdzić, że obraz Galicji autonomicznej przedstawiony w podręcznikach powstałych po 1945 roku pozostał zadziwiająco stały.

\section{Podsumowanie}

Podsumowując całość wywodów przedstawionych w niniejszym artykule, pozwolę sobie uczynić to w formie punktów. A zatem:

1) Podręczniki szkolne są odbiciem aktualnej polityki historycznej;

2) W podręcznikach powstałych w XIX wieku widzimy odzwierciedlenie poglądów stańczyków i krakowskiej szkoły historycznej (Lewicki) oraz szkoły historycznej warszawskiej (Smoleński);

3) W narracjach podręcznikowych okresu międzywojennego uwidacznia się polityka historyczna rządzących oświatą ugrupowań politycznych: endecji (polityka tzw. wychowania narodowego) oraz sanacji (polityka tzw. wychowania państwowego);

4) Podręczniki powstałe po 1945 roku były podporządkowane ideologii marksistowskiej, jednak da się w nich uchwycić zmieniająca się (chociaż nie zasadniczo) politykę historyczną (od ortodoksyjnego komunizmu stalinowskiego w okresie 1948-1956, po liberalny jego odcień w dwóch ostatnich dekadach PRL-u);

168 Ibidem, s. 26. 
5) Obrazy Galicji skonstruowane w podręcznikach historii były uwarunkowane zmieniającą się $\mathrm{w}$ poszczególnych okresach polityką historyczną.

Kończąc, pragnę wyrazić nadzieję, że artykuł stanie się inspiracją do dyskusji nad relacjami, które zachodziły, zachodzą i zapewne będą zachodzić między historią jako nauką, edukacją historyczną i polityką historyczną, w moim przekonaniu odzwierciedlającą się w podręcznikach szkolnych. Artykuł jest zatem przyczynkiem do dyskusji. 